\title{
Understanding Communication of Sustainability Reporting: \\ Application of Symbolic Convergence Theory (SCT)
}

\begin{abstract}
The purpose of this paper is to investigate the nature of rhetoric and rhetorical strategies that implicit in the standalone sustainability reporting of the top 24 companies of the Fortune 500 Global. We adopt Bormann (1972) SCT framework to study rhetorical situation and how corporate sustainability reporting (CSR) messages can be communicated to the audience (public). The concepts of SCT in the sustainability reporting's communication comes under different types of legitimacy strategies used by corporations as a validity and legitimacy claim in the reports. A content analysis has been conducted and structural coding schemes are developed based on the literature. The schemes are applied to the model of the SCT which recognises symbolic convergent processes of fantasy among communicators in a society. The study reveals that most of the sample companies communicate fantasy type and rhetorical vision in their corporate sustainability reporting. However, the disclosure or messages are different across locations and other taxonomies of SCT framework. This study contributes to the current CSR literature and how symbolic or fantasy understandings can be interpreted by the users. Also, it tells about the persuasion styles adopted by the companies for communication purposes. This study is the theoretical extensions of the SCT and researchers may be interested to further investigate other online communication path such as human rights report, director's report.
\end{abstract}

Keywords Corporate social responsibility $\square$ Sustainability reporting $\square$ Symbolic convergence theory Rhetoric

\section{Introduction}

The purpose of this paper is to investigate the nature of rhetoric and rhetorical strategies that implicit in the standalone sustainability reporting of the top 24 companies of the Fortune 500 Global. A majority of the existing researches on corporate social responsibility (hereafter, CSR) have been conducted within management and organizational theoretical frameworks such as accountability, legitimacy, stakeholder 
management, impression management and political economy (Gray et al. 1996; Lewis 2003; Matten and Moon 2008; Brønn and Vidaver-Cohen 2009; O'Connor and Shumate 2010; Du et al. 2010). Comparatively less attention has been directed in social accounting a2nd management literature towards understanding CSR using communication theory or perspective (Ihlen et al. 2011; Merkl-Davies 2017). Indeed, with the exception of few papers (Tregidga and Milne 2006; Spence 2007, 2009; Spence and Thomson 2009; Laine 2009, 2010; Mäkelä and Laine 2011; Nyberg and Wright 2012) in management and accounting journals, works on CSR communication have been widely published in other fields such as public relations, corporate communication, organizational communication, marketing communication, communication management. See, for example, Ihlen et al. (2011); and May and Zorn (2003). Ihlen et al (2011) argued that communication theory explanation of CSR is important from social constructionist and pragmatic perspectives in order to understand how the meaning of CSR is socially constructed, shared, implemented in organizations in one hand, and how CSR communication creates rhetorical vision and persuade others to retain self-interest of business. Indeed, rhetorical vision and persuasion are considered important mechanisms for constructing and reconstructing social facts (Finnemore 1996; Payne 2001). More broadly, persuasion is 'the process by which agent action becomes social structure, ideas become norms, and the subjective becomes the intersubjective' (Finnemore and Sikkink 1998; Klotz 1999). Scholars like Cox (2010) in communication theory field also argue that environmental communication has two basic functions: first a "pragmatic function in which we educate, alert, mobilize, and persuade others" and second, a "constitutive imaging and imagining the future function, in which language and other symbols themselves help to shape our perceptions about reality and the nature of environmental problems" (p. 36). More broadly, organizational communication scholars have long regarded communication as the process of coordinating actions, creating and maintaining organization through language (Putnam and Nicotera 2009; Weick 1979; Putnam and Pacanowsky 1983; Crossan et al. 1999; Taylor and Van 2000; Crane and Glozer 2016; Trittin and Schoeneborn 2017). Organizations, in other words, emerge in communication (Ihlen et al. 2011; Taylor and Van 2000). Taking communication perspective we so argue that CSR communication is an arena where social standards and expectations for corporate social responsibility are constantly articulated, persuaded negotiated and developed. Spence (2007) argues, the language used by companies through their corporate communications can be viewed as both constitutive, by "providing conceptual guidance for actions [and] policy prescriptions" and 
hegemonic, through the cultivation of "ideological consent" which serves dominant groups within society (Spence 2007, p. 857). In addition, Cross (1991) points out, "Persuasion, the ability to win over an audience and inspire action is, after all, the underlying goal of most corporate correspondence, whether it's trying to create an image, keep goodwill ......" (р. 3). Therefore, sustainability reporting are decidedly persuasive. Because, if corporate cannot persuade their constituencies to read their reporting and respond to them appropriately (i.e. whether working faithfully for the corporation, or believing it is a contributing member of a community or society), then the efforts of communicators (i.e. corporates) have been wasted (Stallworth 2008).

Literature on rhetoric and CSR is meagre in management and social accounting (Dey 2007; Böhling et al. 2017). In addition, CSR rhetoric in the business ethics and management journals that publish CSR studies frequently—such as the Journal of Business Ethics and Business Strategy and the Environment-typically use the term "rhetoric" as a synonym for empty words in contrast to "reality" which is different from what communication theorist prescribed on rhetorical tradition (e.g., Preuss 2005). Despite the fact that rhetorical and persuasion are well rooted in communication theories (Golob and Podnar 2014; Davison 2014) and CSR communication becomes a fundamental to organization's experience, the way CSR communication produce a rhetorical vision, by constructing collective meaning of CSR, employ persuasion strategies in the text and so attempt maintaining legitimacy is not well studied is social accounting literature.

To fill the gap this paper aims to explore the nature of rhetoric and rhetorical strategies that implicit in sustainability reporting produced by global corporation mostly drawing on communication theory perspective. We explore the way top 24 global corporations listed in Fortune 500 create rhetoric visions, persuade audiences (e.g. stakeholders) through textual persuasive linguistic style (e.g. ethos, pathos, Lagos) and use rhetorical strategies to legitimate their position. Rhetoric offers a useful framework for this study. Billig (1987) argues that rhetoric is an essential means to understand issues and make it understandable (Alvesson, 1993). It focuses on the persuasive features in language and justifications ones made that can be studied as rhetorical strategies (Billig 1987; Cheney et al. 2004; Watson 1995). By studying the rhetorical strategies that managers use in sustainability report, it adds to the understanding of how managers create different rhetorical vision and persuade stakeholders regards 
to their CSR. Cheney et al. (2004) argued that 'organisations use rhetoric retrospectively to respond to the rhetorical situations or proactively to frame or anticipate future rhetorical situations' (p. 87). In addition, Brennan and Merkl-Davies (2014) mentioned 'Rhetoric serves to resolve both overt and covert conflicts between two parties and to avoid conflict in the first place' (p. 607). They added that 'Rhetorical approaches emphasises on the strategic or political nature of corporate narrative reporting and communication' (p. 607). In this study, we use rhetoric more than the strategies of persuasion, by taking the wider view that it is a means of human understanding and a process for constructing social reality (Putnam 2004; Watson 1995). Managers are considered to be 'rhetors' that produce and assign meaning in their language use (Billig 1987). This means that what managers communicate and how they attempt to persuade and for what purposes. Such an exploration is underpinned by multiple-theory perspective. We so have drawn upon Symbolic Convergence Theory (hereafter, SCT), Aristotle's (1991) explanation of persuasion and Suchman (1995) explanations of three types of legitimacy strategiespragmatic, moral, and cognitive.

SCT is a general communication theory developed by Bormann (1972) that explains the communicative force of fantasy effecting human action (Shields 2000). It has the root on the school of new rhetoric that emerged in the 1960s that assumes no distinction between rhetoric and reality based on social constructionist perspective (Billig 1987; Perelman 1982; Potter 1996). Unlike above studies we do not aim to reveal social reality rather focus on how people construct versions of social reality in social interaction (Burr 1995). This is in contrast with any other previous CSR studies in which the communication of CSR is seen separated from what is actually being done (Bullis 1997). Aristotle's (1991) explanation of three types of persuasion style in textual communication such as logos (appealing to logic), ethos (appealing to authority), and pathos (appealing to emotion) are very much relevant to understand rhetorical strategies and legitimacy types that global companies pursue. Aristotle (1991) proposed that ethos style of persuasion draws on influencing the audience's perceptions by appealing on ethics. With this style rhetor's present them as an ethical-self with justifications. Logos refers to logical argumentation through language to make appeal based on logic. Rhetors try to justify themselves or issues as logical. Pathos style persuasion appeals to the emotions of the audience and emotional justifications are made to convenience audiences (Aristotle 1991; Cheney et al. 2004). We argue that these three theoretical perspectives are complimentary in understanding the nature and 
strategies of CSRC in sustainability reporting. To achieve the aim of the study following three research questions are set.

RQ1: What types of rhetoric visions are implied in sustainability reporting of global top 24 companies?

RQ2: What persuasion style(s) were used by global top 24 companies in their sustainability reports?

RQ3: To what extent do the rhetoric vision, persuasion styles together support the legitimacy?

We select corporate sustainability reporting (CSR) as an organizational that manifest sustainability discourse by comprising a set of interrelated texts and brings an object or idea into being through producing rhetorical visions (Phillips and Hardy 2002; Chalaby 1996; Taylor and van Every 2000). Moreover, corporate sustainability reporting is that it incorporates significant 'citizenship reports' (Hartman et al. 2007), and improves accountability (Gray et al. 1996). Additionally, it encompasses ethical responsibility (Carroll 1979) to society and discretionary responsibilities (Griffin and Mahon 1997) to the wide range of community. Therefore, sustainability reporting can be seen as an appropriate document for companies to communicate their ethos, pathos and logos to persuade the consumers or interested stakeholders (Higgins and Robyn 2012). In addition, CSR on the internet becomes a popular CSR communication in recent years (e.g. Rodríguez Bolívar 2009; Rolland and O'Keefe 2009; Morhardt 2010; Coombs and Holladay 2013; Manetti and Bellucci 2016; Kiliç 2016; and Pinto and Picoto 2016).

Our paper makes three important contributions to the literature on CSR and communication. First, to the best of our knowledge this is the first study to investigate the link between rhetorical and SCT. The findings of this study have important implications for academic research as the study fills a gap in the literature by investigating the link between CSR rhetorical and SCT.

Second, we explored the CSR's rhetoric and also persuasion in a different platform/framework in order to understand CSR communication in a new dimension. 
Third, we examine the legitimacy channel to explore rhetoric vision and persuasion styles used by the companies which might provide a seed for further investigation for scholars in other communication avenues.

The paper is structured as follows: Section 2 presents the literature review on CSR and rhetoric; Section 3 theoretical framework of the paper; Section 4 shows the research method; Section 5 provides results, findings, and discussions and Section 6 concludes the paper by reporting the limitations of the study and providing recommendations for future research.

\section{Section 2}

\section{CSR and rhetoric literature review}

Communicating CSR is an increasingly important corporate focus (Arvidsson 2009; Ihlen 2008). This is partly due to the fact that different stakeholders are continuing expecting more disclosure on companies CSR performance and actions than ever before. The content of these communications is therefore of both important for stakeholders and managers (Du et al. 2010; Johansen and Nielsen 2011). In this regard, it is essential that managers are making appropriate rhetorical choices not only for that it helps persuading audiences by words but it also structure social relations in a broader sense (Kennedy 1991; Berg 2004).

It was Llewellyn (1990) who published first his in depth research on CSR rhetoric. Looking at Ball Corporation and the pharmaceutical company Eli Lilly, he argued for two types of rhetoric that presents companies as "true believers," with CSR issues taken as black and white term, whereas church types of rhetoric which is more nuanced, but builds on the business case of CSR. Looking at the issue of climate change Livesey (2002) showed how ExxonMobil shifted focus from consequences of global warming to consequences of government policy, turning the Market into a god-term, replacing precaution with prudence, scapegoating government, most scientists, and environmentalists, while portraying itself as the savior of a certain lifestyle (Ihlen 2009a). Compare to Llewellyn (1990) study with Livesey (2002), it showed how rhetoric been used to create and recreate the capitalistic structure 
through justifications. In another study, Livesey and Graham (2007) has also showed how Shell has adopted CSR discourse and sustainable development rhetoric that underpins capitalist economy. Ihlen (2009a), demonstrated that the climate rhetoric of the world's 30 largest companies can be categorized by four main themes. First, scenario theme states that the environmental situation is characterized as grave. This appeals to pathos as described by Aristotle. Second, the actor theme that states that the corporation claims to act in line with the scientific consensus in addressing emissions which can be described as Logos described by Aristotle. Third the relational theme that states that the corporation admits to take measures to reduce its own emissions. Finally, circumstances theme that states that the climate challenge is considered as it provides a business opportunity (Ihlen 2009a). Another research by Onkila (2009) identified three rhetorical forms that corporations employ to justify their environmental legitimacy. First he identified the rhetoric of dominance, by focusing on how corporation present themselves dominant by providing an image of as environmentally responsible actor. Second, he identified the rhetoric of subordination, by focusing on how the corporation has limited influence over other powerful external forces that determine environmental actions. Finally, he focused on the rhetoric of joint action, and mentions how the corporation make coalitions and works for a common goal (Onkila (2009). However, further studies showed that the ethos, logos, pathos and or any legitimacy strategies does not necessarily focus on the real issues rather focused on the success of communication of CSR (Ihlen 2009b; Wæraas and Ihlen 2009). Taking the public relation perspective Heath (2001) argued that even companies relying on successful CSR communication is not necessarily bad (also see, Heath \& Ryan 1989). Adopting Quintilian rhetor idea, He argued that modern organizations need to to be a good organizations that communicate well through interactive dialogical process (Heath 2001). The route to the latter is via public relations practice that builds on an interactive dialogical process (also see, Heath 1993). Compare to communication and rethoric CSR studies that focus on persuasion strategies, legitimacy and public relation perspectives a rhetoric used to identify morality bounded CSR is very limited (Bostdorff and Vibbert 1994; Bostdorff 1992). Bostdorff (1992) showed how rhetoric is used to demonstrate the moral and ethical purpose, as well as how corporations have embraced a highly valued social role. Llewellyn (1990) also argued that CSR rhetoric has a theological root.

However, relatively few studies have investigated the role of rhetoric in accounting (Arrington and Schweiker 1992; Warnock 1992; Hooper and Pratt 1995; McCloskey 1998; Brennan and Gray 2000; 
Aerts 1994, 2001; Young 2003; Clatworthy and Jones 2006). While Arrington and Schweiker (1992) showed how rhetoric plays a role in accounting research being ideas argued by peers, Warnock (1992) has considered the role that rhetoric plays in accounting standards (Young 2003; Masocha and Weetman 2007). Hooper and Pratt (1995) have considered rhetoric as ideological articulation by European directors and showed how that created discourse among Maori shareholders and the directors. This is done in a New Zealand case company. In another case, Brennan and Gray (2000) analyses rhetoric and argument in profit forecasts and take-over documents, defining rhetoric as the art of persuasion. They found that considerable effort was made to persuade relevant parties. Other research has analysed the textual languages for exploring the device of metaphor in creating rhetoric (Amernic 1996)

In line with accounting research, discourse studies specific to CSR in rhetoric tradition has particularly focused exploring the device of metaphor and took the critical analysis of case studies (Tregidga and Milne 2006; Masocha and Weetman 2007; Spence 2007; Laine 2010, Tregidga et al. 2014). For example, Spence (2007) argues that CSR communication can be constitutive in a sense that it provide guidance for actions and it is also hegemonic that create "ideological consent" to serves dominant groups within society (Spence 2007). In such as sense, CSR rhetoric is seen to produce and reproduce capitalistic social relations. For example, Banerjee (2003) suggests that sustainable development discourse has "domination effects" (p. 168) that ensures "economic rationality" over "ecological rationality" (p. 174). Milne et al. (2006), came to same view by exploring the metaphor used in corporate communication related to sustainability issues. According to them, the use of "journey metaphor" in one hand implies organisational transition with the lack of reference to the destination of the journey undermines any discussion from corporations regards to "desirable future states of living, and neatly sidesteps any debate about, or need to radically change course" (Milne et al. 2006, p. 825). They conclude that the rhetoric linguistic strategy serves to "further reinforce business as usual" (Milne et al. 2006, p. 801). In a recent study, Tregidga et al. (2013) also suggest similar view.

To summarize, rhetorical scholars and social accounting scholars have not engaged much with the rhetoric in CSR communication. Although above studies highlight the potential role of rhetoric in CSR most of them gone to the critical research fashion using case study and qualitative methods. In addition, 
despite providing important insights, these papers are limited to metaphor analysis rather than a formal analyses of languages using some of rhetoric theories such SCT. It can be argued that CSR rhetoric can have a moral, legitimacy or public relation root in a narrow sense, and creating organization and social relations in a broader social constructionist sense. So far, however, due to few studies only dedicated on rhetorical perspective that mainly focusing on case studies, a quantitative study considering global corporations from different country context would be an important methodological improvement to explore how corporations build such rhetoric, take different rhetorical strategies and constitutes different types of legitimacy in general. More importantly, use of multiple theoretical lenses would provide more dipper understanding of CSR and rhetoric.

\section{Section 3}

\section{Symbolic Convergence Theory (SCT), Rhetorical vision, persuasion and legitimacy-a theoretical} Framework

Building on the socio-psychological and rhetorical (humanistic) traditions of communication Bormann (1972) developed symbolic convergence theory (SCT) (Park et al. 2016). This theory affirms that communities are formed and maintained by the stories they share (Estava 2012). The theory also suggests that humans are storytellers and share dramatization of an event. They make sense out of complexities by creating a script or narrative to account for what happened (Sovacool and Ramana 2015). People share the symbolic facts called fantasies, cues, and types with each other (Park et al. 2016; Shields 2000). They reiterate and reconfigure, repeat and embellish, and take the themes as their own. Commonly, the shared symbolic facts then coalesce into a larger, composite drama, called a rhetorical vision which represents the consciousness of its adherents, collectively known as a rhetorical community (Bormann 1972). A group of researchers so use SCT theoretical and analytical framework to study how rhetorical vision is created by rhetors through three technical concepts- basic (fantasy theme), structural (rhetorical vision) and dynamic (master analogue) (Bormann 1972 ${ }^{1}$; Cragan and Shields 1992, 1995; Bormann et al. 2001; Hopkins 2011; Gyimóthy 2014 and Park et al. 2016).

\footnotetext{
${ }^{1}$ For further reading, see Bormann 1980, 1982, 1983, 1985a, 1985b.
} 
Very briefly, a rhetorical vision is created in the communication through linking fantasy themes to a setting, characters, and actions that together form a 'symbolic drama or a coherent interpretation of reality' (Foss 1989, p. 292). Fantasy theme is the basic unit of communication for symbolic convergence which refers to a dramatizing message that may manifest itself in forms such as humor, wordplay, analogy, anecdote, allegory, fable, or narrative about real or fictitious people (Bormann, 1985a). It is expressed in a single phrase, sentence, or an entire paragraph in a written text (Bormann 1980; Bormann, et al. 2001). One example of a 'fantasy theme' would be 'the Government doesn't care about the mentally ill' (Hopkins 2011). When fantasy themes combine with a setting, characters, and actions together provide a credible interpretation of reality, a rhetorical vision is constructed. Fantasy them itself consist of three taxonomies known as fantasy type, symbolic cue, and saga. A fantasy type is a fantasy theme which is repeated within a singular vision and across diverse rhetorical visions. Moreover, fantasy types provide known reference points to understand and create meaning out of future phenomena (Hopkins 2011). For example, the $9 / 11$ atrocities and subsequent Al Qaida proclamations help categorise and make sense out of travel restrictions, increased airport security and any future terrorist activity (Hopkins 2011). A fantasy type also appears to be a shorthand label for a more complete fantasy theme that depicts the major plotline of some rhetorical vision in which large groups of people participate. For example, shorthand phrases like "fetching good out of evil," "the proof is in the pudding," "the dawn of a new day," and "might makes right," may all be thought of as examples of fantasy themes that may appear as plotlines in a diversity of rhetorical visions and are thus deserving of the concept label "fantasy type" (Shields and Preston 1985). A symbolic cue may be a code word, phrase, slogan, and even a nonverbal sign or gesture. A symbolic cue serves to trigger previously shared fantasies and emotions similar to the symbolic cue "publish or perish" for professors (Cragan and Shields 1992, p. 201). Sometimes, group members develop a symbolic cue, which can be regarded as "code word, phrase, slogan, or even a nonverbal sign or gesture" (Cragan and Shields 1995, p. 200). The saga is the oft-repeated story that surrounds a community or organisation. It might be the story of the company's founders and the uphill struggles in their journey of business. It might be the heroic actions of individuals in devastating natural events such as floods or bushfires (Hopkins 2011). The saga, a symbolic cue and fantasy type create a fantasy theme and a rhetorical vision is created in the communication through linking fantasy themes (Foss 1989). 
A rhetorical vision lies at structural level and is a composite drama in which large groups of people participate (Shields and Preston 1985). Bormann (1972) expanded the concepts of setting, characters and actions by introducing four taxonomies: (a) dramatis personae (the actors or players in a story), (b) a plotline (what occurred), (c) a scene (descriptive details), (d) a sanctioning agent (someone or something with authority, such as an agreed upon sense of morality) (Zanin et al. 2016). The dramatis personae are the characters that are given life within the drama (rhetorical vision). Managers can be seen as either villains or heroes or both in the organisational setup so can be the dramatis personae (Hopkins 2011; Ruebottom 2013). A plotline is the action within the rhetorical vision (Endres 1994; Zanin et. al. 2016). An example of plotlines is that 'business as usual' (Zanin et. al. 2016). A scene implies the setting, the place where the action occurs, the place where the actors or personae act out their roles (Shields and Preston 1985). The sanctioning agent is the source that justifies the acceptance and promulgation of a rhetorical vision. It may be a higher authority - God, the High Court, or Parliament. Also, it can be a code of conduct or honour system, such as an organisation's code of ethics (Cragan and Shields 1992, p. 202). All these combined together to form a rhetorical vision.

Dynamic concept is formed at the final stage of SCT analyses. It is deep structure called as 'Master analogue' within which the rhetorical vision is embedded (Bormann et al. 1997). Cragan and Shields (1981) identify three master analogues, which they refer to as 'warring dramas' grounded in the consciousness of communities: a pragmatic rhetorical vision, a social rhetorical vision, and a righteous rhetorical vision (see also Bormann et al. 1997; Cragan and Shields 1995; Park et al. 2016; Zanin et al. 2016). Here, 'pragmatic' is the concerns of expediency, effectiveness, efficiency, maximal return on investment; 'social' is the concerns of friendship, trust, caring, familial links and responsibilities; and 'righteous' is the concerns of right and wrong, moral and immoral, just and unjust (Cragan and Shields 1992). These 'Master analogue' are equally applicable to understand final version of rhetorical visions within the sustainability reporting.

Previous academic researchers with the exception of Park et al. (2016) have explored SCT theory in different fields of study such as literature, arts \& communication, social and even in medical science. 
Kartikawangi (2017) study evaluates the corporate social responsibility policies of multinational corporations in Indonesia under the SCT Theory. The study use SCT analyses in communication content to discover joint meanings that arise in specific communications. Cragan and Shields (1977) utilized fantasy theme analysis to reveal how foreign policy experts view Russia as a villain on the international stage during the Cold War. In another study Cragan and Shields (1992) demonstrated the use of fantasy theme analysis in corporate strategic planning through an SCT. The study of Endres (1994) is related to the analysis of 'Knights of Columbus'. The researcher addresses the dramatic structural components of three distinct rhetorical visions identified in the 'Knights of Columbus' discourse within the SCT framework. However, primary attention has been given to the master analogue that motives each vision, and its place in the social movement's life-cycle. The author analysed articles, speeches, posters, flyers, video, and promotional materials identified a tripartite distinction in the images presented. The study reveals that the 'Knights of Columbus' faces image problem concerning the Columbus quincentennial (p. 306) and a fantasy theme exploration of their public relations response found three rhetorical visions. Shields (2000) study explicated the SCT's ability on how special communication theories emerged as the product of rhetorical visions that contains norms, conventions, and customs for standard participation in a specific communication style. The findings suggest that the concept of rhetorical vision helps to explain the creation, rise, and potential for demise of a style-specific. Stone (2002) used SCT to discern and segment motives for enrolling in professional master's degree programs in the United States and identified that different fantasy types involved in student decisions to enrol. Palenchar and Heath (2002) undertook a study to define the messages that exist in two communities of risk (e.g. high concentration of chemical facilities) by using the principles of fantasy theme analysis and symbolic convergence theory. The researchers investigated document review, interviews, focus groups, and a telephone survey. Analysis indicated that persons who adhere to different perspectives or opinions (measured as rhetorical visions) experience different amounts of uncertainty, control, and support or opposition for the industries that create the risks. Duffy (2003) used it to show how hate groups perceive minority groups in online chat rooms. Drumheller (2005) employed the theory to investigate how teenagers express religious dogma fortune. All of these above studies. Park et al. (2016) quantitative study analysed corporate Web sites, particularly the "About us" Web pages of Fortune 500 corporations based on SCT. The findings revealed (with the help of content analysis) that economic corporate management is the dominant rhetorical vision. The fantasy, in the 
context of SCT, of being a superior company is emphasized by the 500 examined corporations. Such symbolic reality is constructed using corresponding structural tools of Web content, such as dramatis personae, plot line, and scene. In addition, the rhetorical vision and fantasy themes created by the Web sites turned out to be contingent on business classifications (retailer/distributor, manufacturers, and financial/ informational/recreational services). Moreover, their study also identified companies with other types of fantasy themes (such as admirable, futuristic, and competent/stable) and rhetorical visions (such as socially responsible corporate management). Further to contribute to the current literature our study extend Park et al. (2016) by focusing on sustainability report a voluminous communication compare to "about us" web page. We also provided deeper analysis by focusing on rhetorical strategies and legitimacy types organizations are adopting.

Aristotle's persuasion and rhetorical strategies

While Bormann (1972) proposed formation of rhetorical vision, rhetorical strategies often used in the language for persuasion has been developed by rhetorical scholars based on Aristotle's persuasion strategies (Burke 1969, 1982; Nichols 1987; Self 1979; Braet 1992; Garver 1994; Abizadeh 2002; Robinson 2006). Aristotle (1991) proposes three possible methods for constructing a persuasive claim: logos (logical study), ethos (sociology study), and pathos (psychological study) - are derived from the three factors that are apparent in any of the speech: (a) presenting the view that the speaker is a 'trustworthy' character; (b) creating a logical argument or reasoning through the text; and (c) putting the audience in a certain frame and enables the speaker, text, or a combination of the two to arouse the audience's emotions (Burke 1969, 1982; Nichols 1987; Self 1979; Braet 1992; Garver 1994; Abizadeh 2002; Robinson 2006). In other words, logos, pathos, and ethos provide evidences on rhetorical strategies through reflecting on argument implicit in a communication (Burke 1982; Nichols 1987; Self 1979; Abizadeh 2002; Robinson 2006; Higgins and Robyn 2012; Devin and Lane 2014). Based on our research objectives in particular nature of persuasion, we have adopted the SCT framework to capture the rhetoric vision and Aristotle's persuasion strategies (Ethos, Logos and Pathos) to reflect on rhetorical strategies used in sustainability communication (see also, Higgins and Robyn 2012; ). We then link these rhetorical strategies to the legitimacy types companies are seeking. Following Suchman (1995), we address legitimacy types with moral, cognitive, and pragmatic legitimacy 
(Marais 2012; Devin and Lane 2014). Higgins and Robyn (2012) demonstrate how persuasive strategies activate the 'middle ground' discourses of responsible and sustainable business constructed in three social/environmental reports in New Zealand companies. By focusing on Aristotle's rhetorical 'proofs': ethos (credibility), logos (reason), and pathos (emotion), they argue that persuasive strategies facilitate the social effects of discourse by making business-centred understandings of social responsibility and sustainability appear reasonable and trustworthy. Brennan and Merkl-Davies (2014) focuses on the interactive element in social and environmental reporting during a legitimacy threat in the form of a controversy between business organisations and stakeholders over environmental performance. They adopt Aristotle's triangular framework of the rhetorical situation to examine how the writer, the audience, and the purpose of communication interact in the choice of rhetorical strategies used to persuade others. They examine the validity and legitimacy of a claim during a public controversy. Their findings suggest that the outcome of conflicts on social and environmental issues is dependent on the particular attributes of the stakeholders involved. It also comprises stakeholder's ability to harness the power and legitimacy of other key stakeholders.

\section{Legitimacy explanation and rhetorical strategies}

Suchman (1995) study articulated the diverse literature on organizational legitimacy, highlighting similarities and disparities among the leading strategic and institutional approaches (Neilsen, and Rao 1987; Ashforth and Gibbs 1990; Mezias 1990). Suchman (1995) identified three forms of legitimacy: one is pragmatic which is based on audience self-interest; other is moral which is based on normative approval, and another is cognitive which is based on comprehensibility and taken-for-grantedness. Pragmatic legitimacy rests on the self-interested calculations of an organization's most immediate audiences (Suchman 1995). So, audiences (i.e. direct exchanges between organization and audience) are likely to become constituencies, scrutinizing organizational behavior to determine the practical consequences of any given line of activity (Wood 1991; Suchman 1995). Moral legitimacy refers to legitimacy that is positive normative and based on an evaluation of whether an activity of an organization is moral or ethical (Parsons 1960; Aldrich and Fiol 1994; Suchman 1995; Díez-Martín et al. 2013). The final kind of legitimacy, cognitive legitimacy, refers to legitimacy at the level of taken-for-grantedness rather than the level of evaluation (Suchman 1995). 
By focusing on CSR rhetoric visions (e.g. pragmatic rhetorical vision, a social rhetorical vision, and a righteous rhetorical vision), rhetoric strategies (e.g. Ethos, Pathos, Lagos) we study how managers use sustainability reporting in order to gain legitimacy. Specifically, we focus on how managers develop their company's moral, cognitive and pragmatic legitimacy (Suchman 1995) by building link between CSR rhetorical strategies and legitimacy types based on Marais's study (2012). Marais (2012) suggests that moral legitimacy will be assumed by managers and reflected in corporate communication through justification organizations made with focusing on values, ethics or principles (see also, Reynolds and Yuthas, 2008). In such a case "Pathos" rhetorical style is common. Marais (2012, p. 229) states "Humanism, benevolence, diversity and openness to others are good examples of this type of value. When CEOs use this CSR rhetorical category, they try to improve their company's moral legitimacy by mobilizing emotional arguments and by creating a shared positive vision of its mission. In this case, the use of a "pathos" rhetorical style is very common." To develop cognitive legitimacy, managers may provide examples of actions implemented by the company in order to give stakeholders tangible proof of its true CSR commitment. In this regard, using "ethos" rhetoric style of CSR is relevant to provide an impression of a normative obligation relative to CSR. Marais (2012, p. 229) states "Normative CSR engagement seeks to enhance corporate cognitive legitimacy. It helps to build corporate acceptability by making claims about the willingness to follow widely accepted CSR norms/standards. In this case, CEOs search to create trust among partners. They do not use rational arguments but simply make statements regarding CSR that are expected of them; for example, the expression of broad principles about sustainability. An "ethos" rhetorical style is coherent with this objective." Last, pragmatic legitimacy can be demonstrated by organization based on fact that powerful stakeholders have their own interest on organization. They will only grant legitimacy if their interest been served by the organization. In such a case, managers will communicate bbusiness outcomes that really satisfies stakeholders such as an improved company reputation, the attraction of talented employees, enhanced product quality, more innovation, cost reduction, and so on (Marais 2012). We expect "Logos" based rhetorical strategies in CSRC in such a case. Marais (2012, p. 229) states "Instrumental CSR engagement helps CEOs to convince stakeholders that CSR will lead to benefits for the company. They use rational arguments and examples of positive outcomes of CSR commitment. This rhetorical category is useful to develop corporate pragmatic legitimacy and a "logos" rhetorical style is required." 
Accordingly, we set up our framework based on multiple theory framework based on-SCT, Persuasion and Legitimacy explanations. As shows in Table 1, in corporate setting, it is significant to understand what kind of a composite drama can catch-up large audiences in a symbolic reality and what fantasy themes are repeated to structure rhetorical vision that creates a type of 'Master analogue' in the form of pragmatic rhetorical vision, a social rhetorical vision, and/or a righteous rhetorical vision. Second, the rhetorical strategies are identified through Aristotle's persuasion styles of Lagos, pathos and ethos and examine how these strategies are related to maintaining three different types of legitimacies- pragmatic, moral and cognitive. Maignan and Ferrell (2002) argued that an important aspect of CSR is to act organisation's legitimacy as a function of its contributions to society through philanthropic and ethical practices (Park et al. 2016). In this way, our multiple theory framework contributes in the social accounting literature in three key theories.

Table 1

Symbolic Convergence Theory (SCT)

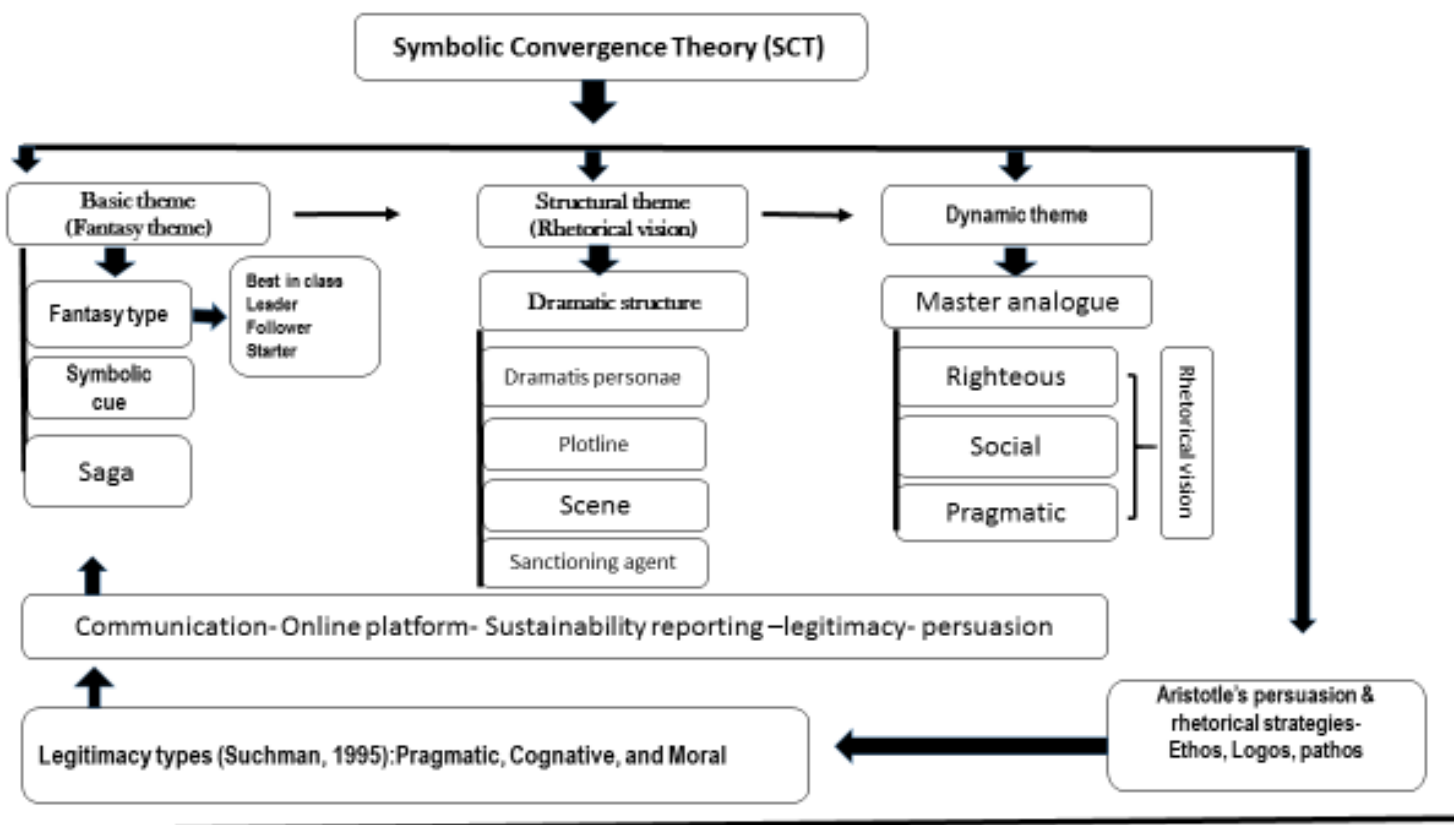

Source: Build on Cragan and Shields 1992; Hopkins 2011; Higgins and Robyn 2012; Marais 2012; and Devin and Lane 2014, Zanin et al. 2016; Park et al. 2016 and our theoretical framework discussion.

Section 4

\section{Methodology}

\section{Sample}


The sample selection procedure is reported in Table 2. The sample consists of top 30 companies in terms of revenue among the Fortune Global 500 companies around the world. The sample consists of various categories of industries such as: petroleum (6), automobiles (5), technology (2), financial (2), telecommunication (2), electronics (2), and Others including retail, power, energy, health care, Motor Vehicles \& Parts (5). We exclude 6 companies due to unavailability of sustainability reporting ${ }^{2}$. Therefore, the total samples reached to 24 companies. The data for our analysis comes from 11 different countries (e.g., China, France, Germany, Italy, Japan, Netherland, Switzerland, South Korea, Taiwan, United Kingdom, and United States) and is well active in CSR including sustainability reporting. A breakdown of industry classification according to geographical location has been also provided in Appendix 1.

Table 2

Description of the sample

\begin{tabular}{|c|c|c|c|c|c|}
\hline \multirow[t]{2}{*}{ Sample Size } & \multirow[b]{3}{*}{30} & \multicolumn{4}{|l|}{ Sample Characteristics } \\
\hline & & \multicolumn{2}{|l|}{ Industrial Categorization } & \multicolumn{2}{|c|}{ Geographical Categorization } \\
\hline Initial Sample & & Petroleum & 6 & American & 10 \\
\hline sustainability & 6 & & & Asian & 8 \\
\hline Report & & Automobiles & 5 & & \\
\hline & & Technology & 2 & European & 6 \\
\hline & & Financial & 2 & & \\
\hline & & Telecommunications & 2 & & \\
\hline & & Electronics & 2 & & \\
\hline & & Others & 5 & & \\
\hline Final Sample & 24 & Total & 24 & & 24 \\
\hline
\end{tabular}

Source: http://beta.fortune.com/global500

\section{Method and Coding Procedure}

This study used content analysis as a technique to identify and describe patterns \& structure on- line sustainability reports of the sample companies. According to Neuman (2003, p. 219) "content analysis is a technique for gathering and analysing the content of text. The content refers to words, meanings, pictures, symbols, ideas, themes, or any message that can be communicated". It involves codifying qualitative and quantitative information into pre-defined categories to derive patterns in the presentation and reporting of information (Guthrie et al. 2004; Unerman 2000). The first two authors independently carried out content analysis task. We have consulted the studies of sustainability such as Roberts

\footnotetext{
2 The terms "'sustainability," "'environmental, social, and governance", (ESG), and "corporate social responsibility" (CSR) have been used interchangeably in the past to describe a firm's voluntary actions to manage its environmental and social impact and increase its positive contribution to society (Khan et al. 2016). Therefore, we considered different names like corporate citizenship report or environment responsibility report as the sustainability report under the study and focus on 2015 report.
} 
(1992), Carroll (1998), Deegan (2002), Gray et al. (1995), Coombs and Holladay (2013) in order to understand theme for coding of sustainability reporting.

\section{Coding Measurement}

The following section provides the methodological aspects of the coding measurement on each taxonomies.

\section{Fantasy type under the basic theme (fantasy theme)}

In order to identify the fantasy type, we have recognized the four fantasy types including 'best-in-class', 'leader', 'follower', and 'starter' which were used by other authors (Chen et al. 2015; Dong and Xu 2016). In this regard, we have identified four key areas on which disclosures are addressed in the sustainability reporting as suggested by GRI standard 2016. GRI is an independent international organization that has pioneered sustainability reporting since 1997 (GRI 2016). We have followed GRI theme because, "The GRI Standards create a common language for organizations and stakeholders, with which the economic, environmental, and social impacts of organizations can be communicated and understood" (GRI, 2016, p. 6). In this regard, we have covered four areas of disclosure such as corporate reporting practice, sustainability development, good governance and employability and Philanthropy. Each area is coded 1 if the company disclosed narrative forms. Bormann (1980) argued that fantasy them can be expressed in a single phrase, sentence or an entire paragraph in a written text and also fantasy them itself consist of fantasy type including symbolic cue and saga. Accordingly, if companies disclosed all four areas in the report, then maximum score 4 was awarded and therefore assigned that particular company to the 'Best in class' fantasy type. Those companies were received score 3, 2 and 1, they have been assigned to 'leader,' followed by 'follower' and 'starter' fantasy type respectively. However, in terms of symbolic cue (for example, slogan) and saga (for example, story), we do not found or identified sufficient theme in sustainability reporting as guided by (Cragan and Shield 1995), therefore not reported. A detailed coding and measurement abstract is provided in Appendix 2.

\section{Rhetorical vision under structural theme}


There are four components under the dramatic structure in the rhetorical vision. We identified the rhetorical and discursive devices that theses sustainability reporting use to communicate to audience. The possible characters/actors/models/theme for each component within the rhetorical vision identified by the first four authors independently after reading five different sustainability reporting. In the above phase of analysis, the full set of sustainability reporting was analysed line-by-line to develop a working schema, then categories were modified and refined based on subsequent review among the authors (Goetz and LeCompte 1984). In addition, we also considered sensitizing concepts (Blumer 1954; Van den Hoonarrd 1997) and used in the coding process in the line with Carroll's (1991) pyramid of CSR. Social researchers now tend to view sensitizing concepts as interpretive devices and as a starting point for a qualitative study (Glaser 1978; Padgett 2004; Patton 2002). Charmaz (2003) has referred to sensitizing concepts as "those background ideas that inform the overall research problem" (p. 259). CSR is 'sensitizing concept' (Jonker 2005): a term that draws attention to a complex range of issues and elements that are all related to the position and function of the business enterprise in contemporary society (p. 20). To ensure accuracy, reliability and validity of the coding has also been tested statistically which is reported in the validity and reliability paragraph under section 4 . The first components is the dramatis personae who are the actors on the vision's stage. Within organisations, for example, 'Dramatis Personae' refers to the cast of characters report in sustainability reporting. In this study, we have assumed 'dramatis personae' are the characters or models that appear in the reporting. This may be behind employees, environment, society, and the technology. Therefore, we have coded accordingly and ensure each company receive only one personae. The second one is 'Plot line' which is the action or behaviour embedded in the rhetorical vision (Park et al. 2016). Response of satisfied customers and key stakeholders are coded as customer satisfaction. Actions that show reduction in energy consumption and greenhouse gas emissions are coded as energy efficiency. Actions illustrating the corporations reaching their objectives by sprit of groups are regarded as team work. On the other hand, actions that are advocating green living for environmental protection is coded as green world. The third one is 'Scene' which we understand as place or background where the dramatis personae and plot line takes place. In this case, we found three scenes i.e. corporation itself, environment, and society. In this case, visual images considered as it contributes to the rhetorical structure of a message (Gamson and Modigliani 1989). In coding process, we adopt the method of Park et al. (2016). So, in these scenarios, 'corporation' is coded when pictures of actual corporation appear. When scene presented natural setting 
of mountains, ocean, soil and clouds, we coded them as 'environment'. When corporations presented pictures of their social activities in schools, charitable institutes, scientific and technology innovation, we coded them as 'society' (Park et al. 2016). The last component is the 'sanctioning agent' which is 'the justification or the representing agent of the rhetorical vision' (Park et al. 2016, p. 720). In this regard, we identified five sanctioning agents including employee, customer, community, general public and globalisation. Employee agent is the description of corporation's key elements that leads to the success story. Customer agent is the description of the sustainable business strategy based on customers' priorities. Community agent describes the corporation as ethical and giving back to the community. General public agent is the description of corporation which is creating jobs globally. And finally, globalising agent is the description of the corporation being world class and internationally recognised. In the above phrase, sensitizing concepts (Van den Hoonarrd 1997) were used. All those descriptions are coded against dominancy of the above agents for each company. The dominancy has been calculated on the basis of identified key words occurred (in terms of times) in each taxonomies in the sustainability reporting with the help of NVivo. For example, in dramatis personae, if the 'employee' occurred highest percentage, then that particular company has been coded as 'employee'. In the similar way we have coded rest of others taxonomies. After that, we have counted total number of companies against each and every SCT taxonomies and made a number of cross tabulation on fantasy type (Table 5), rhetorical vision (Table 6) and geographical location (Table 7) respectively. Table 3 provides the coding and measurement for rhetorical vision under structural theme. 
Table 3

Coding and measurement for rhetorical vision

\begin{tabular}{|c|c|c|c|c|c|}
\hline & \multicolumn{4}{|c|}{ Dramatic structure } & \multirow[b]{2}{*}{ Coded } \\
\hline & & Theme & Descriptions/justifications & Dominances/occurred & \\
\hline 1 & $\begin{array}{l}\text { Dramatis } \\
\text { personae }\end{array}$ & $\begin{array}{lr}\text { Actor(s)- } & \text { the } \\
\text { characters } & \text { that } \\
\text { appear in the } \\
\text { message }\end{array}$ & $\begin{array}{l}\text { The unit of analysis is CSR report which is considered an accountability } \\
\text { representation of corporations to the diverse set of stakeholders. Therefore, for } \\
\text { dramatis personae, all the actors having stake with the activities of corporations are } \\
\text { considered. We found, for example, employees, environment, society, and } \\
\text { technology as actors. }\end{array}$ & $\begin{array}{l}\text { Highest percentage of } \\
\text { characters/actors } \\
\text { appear in the report. }\end{array}$ & $\begin{array}{l}\text { Employees } \\
\text { Environment } \\
\text { Society } \\
\text { Technology }\end{array}$ \\
\hline 2 & Plotline & $\begin{array}{l}\text { Action or behaviour } \\
\text { embedded in the } \\
\text { rhetorical vision. }\end{array}$ & $\begin{array}{l}\text { Response of satisfied customers and key stakeholders are coded as customer } \\
\text { satisfaction. Actions that show reduction in energy consumption and greenhouse gas } \\
\text { emissions are coded as energy efficiency. Actions illustrating the corporations } \\
\text { reaching their objectives by sprit of groups are regarded as team work. On the other } \\
\text { hand, actions that are advocating green living for environmental protection is coded } \\
\text { as green world. }\end{array}$ & $\begin{array}{l}\text { Highest percentage of } \\
\text { characters appear in the } \\
\text { report. }\end{array}$ & $\begin{array}{l}\text { Customer } \\
\text { satisfaction } \\
\text { Energy efficiency } \\
\text { Team work } \\
\text { Green world }\end{array}$ \\
\hline 3 & Scene & $\begin{array}{l}\text { It refers to the place } \\
\text { or background } \\
\text { where dramatis } \\
\text { personae develops } \\
\text { the plotline (Park et } \\
\text { al., 2016) }\end{array}$ & $\begin{array}{l}\text { To code this, three different categories were used: corporation itself, environment, } \\
\text { and society. 'Corporation' is coded when pictures of actual corporation appear. When } \\
\text { scene presented natural setting of mountains, ocean, soil and clouds, we coded } \\
\text { them as 'environment'. When corporations presented pictures of their social activities } \\
\text { in schools, charitable institutes, scientific and technology innovation, we coded them } \\
\text { as 'society'. }\end{array}$ & $\begin{array}{l}\text { Highest percentage of } \\
\text { characters appear in the } \\
\text { report in the form of } \\
\text { visual images as } \\
\text { defined in description } \\
\text { area. }\end{array}$ & $\begin{array}{l}\text { Corporation itself } \\
\text { Environment } \\
\text { Society }\end{array}$ \\
\hline 4 & $\begin{array}{l}\text { Sanctioning } \\
\text { agent }\end{array}$ & $\begin{array}{l}\text { It is about the } \\
\text { justification of the } \\
\text { rhetorical vision. }\end{array}$ & $\begin{array}{l}\text { To code this, five categories were used in this study. Employee agent is used if the } \\
\text { corporation works extensively with its employees. Consumer agent shows } \\
\text { corporations' efforts on the interests of consumers. To refer the corporate efforts in } \\
\text { the community level, community agent code is used. General public agent } \\
\text { emphasizes on corporations' efforts in the mass level which is beyond community. } \\
\text { Finally, globalization agent is used to mark corporations' efforts in the international } \\
\text { level crossing national boundaries. }\end{array}$ & $\begin{array}{l}\text { Highest percentage of } \\
\text { characters appear in the } \\
\text { report. }\end{array}$ & $\begin{array}{l}\text { Employee agent } \\
\text { Customer agent } \\
\text { Community agent } \\
\text { General public } \\
\text { agent } \\
\text { Globalization } \\
\text { agent }\end{array}$ \\
\hline
\end{tabular}

Source: Park et al. 2016; Van den Hoonarrd 1997; Goetz and Lecompte 1984 


\section{Master analogue under dynamic theme}

Under Master analogue category, there are three master analogues i.e. righteous, social and pragmatic master analogue (Cragan and Shields 1995). The coding is also based on dominancy of the above righteous statements in the sustainability reporting. We have determined the dominancy in the percentage (NVivo) of associate theme in each analogue. Table 4 that shows how the coding process is completed. 
Table- 4

Coding for Master Analogue (MA)

\begin{tabular}{|c|c|c|c|c|c|}
\hline & Meanings & $\begin{array}{l}\text { Associated } \\
\text { themes/langu } \\
\text { age used }\end{array}$ & $\begin{array}{l}\text { Dominances/occur } \\
\text { red }\end{array}$ & Original text excerpt & Coded \\
\hline $\begin{array}{l}\text { Righteous } \\
\text { MA }\end{array}$ & $\begin{array}{l}\text { "Stresses the correct way of } \\
\text { doing things with its } \\
\text { concerns about right and } \\
\text { wrong, proper and improper, } \\
\text { superior and inferior, moral } \\
\text { and immoral and just and } \\
\text { unjust" (Cragan and Shields } \\
\text { 1995, p. 42). }\end{array}$ & $\begin{array}{l}\text { Responsibility, } \\
\text { economic, } \\
\text { ethics, society, } \\
\text { social } \\
\text { contribution }\end{array}$ & $\begin{array}{l}\text { Highest } \\
\text { percentage of } \\
\text { associated themes } \\
\text { appear in the } \\
\text { report. }\end{array}$ & $\begin{array}{l}\text { ABC firstly persisted in fulfilling economic responsibility, believing that } \\
\text { serving "Sannong" and poverty alleviation as the core and the most basic } \\
\text { responsibility. We undertake the responsibility in economic transformation, } \\
\text { customer service, supporting the frontier and other aspects. With our net } \\
\text { profit and tax payment steadily growing, social contribution value per share } \\
\text { has increased year after year. Secondly, we have complied with the social } \\
\text { responsibility standard guidelines and ethics at home and abroad, } \\
\text { improved our social responsibility system, enhanced our social } \\
\text { responsibility information disclosure, and integrated the philosophy of } \\
\text { "Giving Priority to Responsibility and Benefiting All the People; Taking } \\
\text { Responsibility, and Promoting Prosperity in Our Society" into our } \\
\text { operational and management reform. [ABC Ltd. p. 4] }\end{array}$ & $\begin{array}{l}\text { Responsibility, } \\
\text { economic, } \\
\text { ethics, society, } \\
\text { social } \\
\text { contribution }\end{array}$ \\
\hline Social MA & $\begin{array}{l}\text { "Emphasizes primary human } \\
\text { relation as it keys on } \\
\text { friendship, trust, caring, } \\
\text { comradeship, compatibility, } \\
\text { family ties, brother hood, } \\
\text { sisterhood } \\
\text { humaneness" (Cragan and } \\
\text { Shields 1995, p. 42). }\end{array}$ & $\begin{array}{l}\text { Community, } \\
\text { culture, } \\
\text { network, } \\
\text { customer, } \\
\text { caring }\end{array}$ & $\begin{array}{l}\text { Highest } \\
\text { percentage of } \\
\text { associated themes } \\
\text { appear in the } \\
\text { report. }\end{array}$ & $\begin{array}{l}\text { We create an engaging employee experience in which our work makes a } \\
\text { difference. Our culture encourages employees to innovate and thrive on } \\
\text { challenges, build the world's most awesome networks, and deliver } \\
\text { personal technology solutions that makes life better. Our commitment to } \\
\text { one another and our customers starts with the Verizon Credo, an } \\
\text { aspirational foundation for who we are and how we work. [Verizon, p. 59] }\end{array}$ & $\begin{array}{l}\text { community, } \\
\text { culture, } \\
\text { network, } \\
\text { customer, } \\
\text { caring }\end{array}$ \\
\hline Pragmatic & $\begin{array}{l}\text { "Accentuates expediency, } \\
\text { utility, efficiency, parsimony, } \\
\text { simplicity, practicality, cost } \\
\text { effectiveness, and whatever } \\
\text { it takes to get the job } \\
\text { done."(Prentice 2006) }\end{array}$ & $\begin{array}{l}\text { Risk, } \\
\text { Threats, } \\
\text { Efficacy } \\
\text { Cost } \\
\text { Environment }\end{array}$ & $\begin{array}{l}\text { Highest } \\
\text { percentage of } \\
\text { associated themes } \\
\text { appear in the } \\
\text { report. }\end{array}$ & $\begin{array}{l}\text { Shell has long taken into account the potential risks and threats to the } \\
\text { viability and profitability of major projects to ensure the robustness of our } \\
\text { portfolio. [Shell, p. 17] }\end{array}$ & $\begin{array}{l}\text { Risk, } \\
\text { Threats, } \\
\text { Efficacy } \\
\text { Cost } \\
\text { Environment }\end{array}$ \\
\hline
\end{tabular}

Source: Sustainability reports of ABC (2015); Verizon (2015) and Shell (2015) 


\section{Aristotle's persuasion \& rhetorical strategies}

Once we set up the types of legitimacy involve in the rhetorical coding, our next step is to determine the Aristotle's persuasion \& rhetorical strategies in the sustainability reporting and then link to the types of legitimated. In this case, the genre analysis theory (Bazerman 1995; Bhatia 1993; Levina and Orlikowski 2009; Mason and Mason 2012) guided our coding parsing of the data. Genres theory as "socially recognised types of communicative actions that are habitually enacted by members of a community to realize particular social purposes" (Levina and Orlikowski 200, p. 542). We analysed the macrostructure of each sustainability report by coding the type of discourse move (Bazerman 1989; Bhatia 1993, 2004; Swales and Rogers 1995). Moves (Swales 1990) are structural elements that deliver the content of the genre and are classified by type of rhetorical function or theme (Bhatia 1993). Across reporting genres, the three common moves such as logos, ethos and pathos are identified as persuasion. Our analysis of the data for these three moves are specific to the genre. This classification method establishes the type, rate, and frequency of each rhetorical move in order to discover the companies' rhetorical preferences and hierarchical sequencing (i.e., priorities) when reporting on their environmental commitments, goals, and ideology and discharge of legitimacy. For example, in the following paragraph in the sustainability report of the Walmart (2015), Walmart used this type of move (i.e. ethos) to establish its support to the global agenda to the environment as trustworthy in the corporate sustainability reporting:

"Walmart has grown into the world's largest retailer. We have stores in 10,000 communities, employing more than 2.2 million associates and thousands of suppliers who, in turn, employ millions of people. Because of our heritage, we seek to use our scale and capabilities to help others - not only customers and other Walmart stakeholders, but also society at large" (p. 2).

Therefore, the above statement/theme satisfy the ethos and cognitive legitimacy definitions (see more in section 3), we coded 'ethos' and 'cognitive legitimacy' for each company. By combining these three types of genres, a corporate sustainability report informs audience/stakeholders of the company's actions and efforts to protect the environment and promotes an image of good environmental stewardship (Mason and Mason 2012).

The Table 5 provides examples of coding process of Aristotle's persuasion \& rhetorical strategies of some selected companies with examples of original text excerpt. 
Table: 5

Coding for Aristotle's persuasion \& rhetorical strategies

\begin{tabular}{|c|c|c|c|c|c|}
\hline $\begin{array}{l}\text { Aristotle's } \\
\text { persuasion } \\
\& \text { rhetorical } \\
\text { strategies }\end{array}$ & $\begin{array}{l}\text { Argumentation } \\
\text { process }\end{array}$ & $\begin{array}{l}\text { Associated } \\
\text { themes/language used }\end{array}$ & $\begin{array}{l}\text { Moves } \\
\text { (Swales } \\
1990)\end{array}$ & Original text excerpt & $\begin{array}{l}\text { Types of } \\
\text { legitimacy }\end{array}$ \\
\hline Ethos & $\begin{array}{l}\text { Projecting the speaker } \\
\text { as trustworthy delivered } \\
\text { on global } \\
\text { environmental, social, } \\
\text { employee, society and } \\
\text { technology }\end{array}$ & \begin{tabular}{lr|}
\multicolumn{2}{l}{ Global agenda, expression of } \\
CSR, $\quad$ institutionalised \\
structure, $\quad$ acceptability, \\
principles, $\quad$ defence, \\
expertise, $\quad$ consistency, \\
inclination to succeed
\end{tabular} & & $\begin{array}{l}\text { Walmart has grown into the world's largest retailer. We have stores } \\
\text { in } 10,000 \text { communities, employing more than } 2.2 \text { million associates } \\
\text { and thousands of suppliers who, in turn, employ millions of people. } \\
\text { Because of our heritage, we seek to use our scale and capabilities } \\
\text { to help others - not only customers and other Walmart } \\
\text { stakeholders, but also society at large. [Walmart, P. 2] }\end{array}$ & $\begin{array}{l}\text { Cognitive } \\
\text { legitimacy }\end{array}$ \\
\hline Logos & $\begin{array}{l}\text { Logos -Showing the } \\
\text { probability of what is } \\
\text { said by using a logical } \\
\text { and rational argument. }\end{array}$ & $\begin{array}{l}\text { Enhancing Reputation, } \\
\text { Motivation, talent attraction, } \\
\text { Value creation, innovation, } \\
\text { Claims, justifications, Data, } \\
\text { evidence/example, } \\
\text { Argumentation }\end{array}$ & & $\begin{array}{l}\text { We added } 13 \text { underserved middle schools to the VILS program in } \\
2015 \text {, providing nearly } 9,000 \text { students and teachers with a tablet } \\
\text { and two years of Internet access. [Verizon, p. 13] }\end{array}$ & $\begin{array}{l}\text { Pragmatic } \\
\text { legitimacy }\end{array}$ \\
\hline Pathos & $\begin{array}{l}\text { Pathos - Considering } \\
\text { the emotions of the } \\
\text { audience in order to } \\
\text { induce them to make } \\
\text { the desired judgement. }\end{array}$ & $\begin{array}{l}\text { Use of emotive language, } \\
\text { First person narrative, Use of } \\
\text { metaphors }\end{array}$ & & $\begin{array}{l}\text { I see so many opportunities for our CSR strategy to play a bigger } \\
\text { and more significant role in supporting our business, while } \\
\text { delivering more value to our communities and stakeholders. [CVS } \\
\text { Health, p. 5] }\end{array}$ & $\begin{array}{l}\text { Moral } \\
\text { legitimacy }\end{array}$ \\
\hline
\end{tabular}

Source: Sustainability reports of Walmart (2015); Verizon (2015) and CVS Health (2015); adopted from Marais (2012); Suchman (1995) 


\section{Validity and reliability}

To examine the construct validity of our coding procedure, we selected a random sample among the six sustainability reports. The first four authors independently coded of the corresponding reports. The coders have discussed all the doubts and ambiguity and then allocated the relevant score of the sustainability content of the report. After coding, one of the authors tested the reliability and validity by using Scott's Pi, Cohen's Kappa and Krippendorff's alpha techniques. It produced the following results: Percentage agreement $=0.918$, Scott's $\mathrm{Pi}=0.892$, Cohen's Kappa $=0.892$ and Krippendorff's Alpha $=$ 0.893. All of these results are within the acceptable range (Scott 1995; Cohen 1960; Krippendorff 1980; Hayes and Krippendorff 2007).

\section{Section 5}

\section{Results, findings and discussions}

In order to investigate our RQ 1, we have prepared Table 5 for thematic discussion of the rhetoric of the sample companies implied in the sustainability reporting within the SCT framework. Table 5 represents disclosure status of the companies under fantasy theme against other SCT concepts such as rhetorical, dramatic and master analogue. It can be observed from the Table 5 that the most frequent rhetorical vision under the 'Best in class' fantasy type is the logos $(66 \%, n=4)$ followed by ethos $(16.7 \%$, $\mathrm{n}=1)$ and then pathos $(16.7 \%, \mathrm{n}=1)$. However, in the 'Leader' fantasy type, rhetorical visions of ethos $(45 \%, n=5)$ appeared most frequently followed by logos $(36.4 \%, n=4)$, and pathos $(18.2 \%, n=2)$. On the other hand, fantasy types of 'Follower' and 'Stater', rhetorical visions of the ethos, logos and pathos appeared least in all other fantasy types (range $25 \%$ to $33.33 \%, n=1$ ). Moreover, out of 24 companies, the highest numbers of companies i.e. 11 falls under the 'Leader' fantasy type. This indicates that company's rhetoric and persuasion depends on company's involvement in CSR management, GRI or global standard and CSR performance. With regard to dramatis personae, all four fantasy types involve almost all types of dramatis personae in the sustainability reporting with the exception of 'Society' under best in class \& starter fantasy type; 'technology' under leader and starter fantasy type. On the other hand, a total of nine companies (38\%), a dramatis personae of 'Environment' plays in all four types of fantasy followed by 'Employee' ( $n=7,29 \%)$; and 'Society' ( $n=6,25 \%)$. A dramatic personae of 
'Technology' $(n=2,8 \%)$ is seen least in all the fantasy types. In terms of plot line, 'Energy efficiency' $(50.0 \%, n=3)$ is appearing most frequently in the 'Best in class' and 'Follower' fantasy types, followed by customer satisfaction $(36.4 \%, n=4)$ in the 'Leader' fantasy type. However, plot line for 'Customer satisfaction' occupies highest number $(n=7,29 \%)$ as well as 'Energy efficiency' also occupies highest number of companies $(n=7,29 \%)$ in the sample. In addition, no companies $(n=0)$ are seen in the plot line for 'Green world' under the 'Best in class' fantasy type followed by 'Team work' under 'Follower' and 'Energy efficiency' under 'Starter' fantasy type. With regards to scene, society appeared mostly under 'Leader' ( $n=9,81.8 \%)$ fantasy type, followed by 'Best in class' ( $n=3,50 \%)$, 'Starter' ( $n=2,66.7 \%)$ and 'Follower' ( $n=1,25 \%)$. In terms of sanctioning agent, globalisation agent is found most under fantasy type 'Leader' ( $n=5,45.5 \%)$, followed by 'Best in class' $(n=3,50 \%)$, and 'Starter' $(n=1,33.3 \%)$. The distribution in relation to master analogues fantasy type, pragmatic master analogue $(n=3,50 \%)$ appeared most in the 'Best in Class', and then righteous $(n=6,54.5 \%)$ in 'Leader', social master analogue $(n=3,75 \%)$ and $(n=3,66.7 \%)$ in 'Follower' and 'Starter' respectively.

We report our findings in the Table 6 to investigate the second research question (i.e. what persuasion styles were used) of our study. Table 6 represents the distribution of the rhetorical vision against the other concepts of SCT. Therefore, we called the Table 6 cross-tabulation of rhetorical vision and basic \& structural concepts of SCT. It is seen in the Table 6 that the rhetorical vision of 11 companies is in 'Logos' followed by 'ethos' ( $n=8)$ and 'Pathos' $(n=5)$. In terms of fantasy type, 'Leader' occupies highest number $(n=5,62.5 \%)$ in the Aristotle's rhetorical vision of 'Ethos' followed by 'Pathos' $(n=2,40 \%)$ and 'Logos' ( $n=4,36.4 \%)$. However, under the 'Best in class' fantasy type, 'Logo' ( $n=4,36.4 \%)$ appears in most followed by 'Pathos' $(n=1,20 \%)$ and 'Ethos' (12.5\%). For dramatic personae, the presence of rhetorical vision is absent ( $0 \%)$ only in 'Ethos' under 'technology' as dramatic personae. However, highest number of companies ( $n=9,38 \%$ ) address dramatic personae as 'environment' followed by 'employees' $(n=7,29 \%)$ and 'society' $(n=6,25 \%)$. With regard to plot line, the most frequently appearing in the rhetorical vision of 'Ethos' is green world $(n=3,37.5 \%)$, while energy efficiency is the most prominent plot line for companies with 'Logos' ( $n=4,36.4 \%)$ and 'Pathos' $(n=2,40 \%)$ rhetorical vision. In terms of scene, rhetorical vision of 'Ethos' is society ( $n=6,75 \%)$, followed by rhetorical vision of 'Pathos' ( $n=3,60 \%)$ and 'Logos' ( $n=6,54.5 \%)$. However, rhetorical vision of 'Pathos' does not use corporate-related scenes (corporation itself). In terms of sanctioning agent, customer agent is absent 
in the rhetorical vision of 'Ethos', and 'Pathos'. On the other hand, general public agent is absent in the rhetorical vision of 'Pathos'. However, globalisation $(n=4,50 \%)$ is a highly dominant aspect for the rhetorical vision of 'Ethos'. Finally, for master analogues, righteous master analogues $(n=4,50 \%)$ is found highest in the rhetorical vision of 'Ethos' followed by pragmatic master analogues ( $n=5,45.5 \%)$. However, both social master analogues and pragmatic master analogues $(n=2,40 \%)$ receive equal score in the rhetorical vision of 'Pathos'.

To further explore our RQ3, we have prepared Table 8 and shown the number of companies disclose the amount (\%) of Aristotle's persuasion and rhetorical strategies (based on fantasy type)

Table 8 shows that 11 companies (46\%) in 'Ethos' followed by 'Logos' $(n=11,3 \%)$ and 'Pathos' $(n=5$, $21 \%$ ). We also explore on how the geographical locations of the companies are distributed in the concept of SCT, which is reported in Table 7. It can be observed from the Table 7 that companies located in the European region $(n=5,83.3 \%)$ are highest under the 'Best in class' fantasy type followed by Asian $(n=1,12.5 \%)$. On the other hand, companies located in the Asian region $(n=6,75 \%)$ fill the fantasy type 'Leader' followed by companies located in the American region $(n=5,50.0 \%)$. In terms of 'Follower fantasy type, only two companies (20\%) are located in the American region whereas no companies are located in this fantasy type 'Starter' in the Asian or European region. However, ten companies from USA, eight companies from Asian and six companies from European region participated in all SCT practices. In terms of rhetorical vision of 'Ethos' both Asian ( $n=4,50 \%)$ and American companies $(n=4,40 \%)$ occupies highest number in these regions. Yet, four companies from European region (66.7\%) and American region (40\%) reported to demonstrate the rhetorical vision of 'Logos' followed by three companies from Asian region (37.5\%). In contrary, two companies from European and American regions reported to demonstrate the rhetorical vision of 'Pathos' followed by one company (12.5\%) from Asian region. Dramatic personae also show differences according to the companies' location. It is reported in the Table 7 that dramatis personae encompassing all three geographical locations except 'society' in Europe and 'technology' in the American district. However, most dramatic personae 'environment' is presented in the European region $(n=4,66.7 \%)$ followed by 'employees' in the American region $(n=4,40 \%)$. In terms of plot line, 'green world' occupies four 
companies in the Asian region (50\%) followed by 'energy efficiency' four companies $(66.7 \%)$ in the European region and 'customer satisfaction' in the American region. In terms of scene, seven Asian companies ( $87.5 \%)$ reported to validate the 'society' as scene followed by six companies from American region $(60 \%)$ and two from European region. However, 'environment' scene is absent in the Asian region. In case of sanctioning agent, 'globalisation agent' is seen in most of the companies located in the Asian region $(n=4,50 \%)$ followed by American $(n=3,30 \%)$ and European region $(n=2,33.3 \%)$. However, no Asian company has shown sanctioning agent 'customer agent'. Also, no European company has shown sanctioning agent 'general public agent'. Finally, master analogues are also different depending on the companies' location. For example, four Asian companies (50\%) present master analogues of 'righteous' followed by three European companies (50\%) in master analogues of 'pragmatic' and two American companies present master analogues of 'social'. However, the distribution of number of companies as per geographical location and all-encompassing master analogues are satisfactory. 


\section{Table 5}

Cross-Tabulation of Fantasy Type and the Basic and Structural Terms of SCT

\begin{tabular}{|c|c|c|c|c|c|}
\hline \multirow[b]{2}{*}{ Taxonomies } & \multicolumn{5}{|c|}{ Fantasy Type } \\
\hline & $\begin{array}{l}\text { Best in } \\
\text { Class }\end{array}$ & Leader & Follower & Starter & Total \\
\hline \multicolumn{6}{|l|}{ Rhetorical vision } \\
\hline Ethos & $1(16.7 \%)$ & $5(45.5 \%)$ & $1(25.0 \%)$ & $1(33.3 \%)$ & $8(33 \%)$ \\
\hline Logos & $4(66.7 \%)$ & $4(36.4 \%)$ & $2(50.0 \%)$ & $1(33.3 \%)$ & $11(46 \%)$ \\
\hline Pathos & $1(16.7 \%)$ & $2(18.2 \%)$ & $1(25.0 \%)$ & $1(33.3 \%)$ & $5(21 \%)$ \\
\hline Total & $6(100 \%)$ & $11(100 \%)$ & $4(100 \%)$ & $3(100 \%)$ & $24(100 \%)$ \\
\hline \multicolumn{6}{|l|}{ Dramatis personae } \\
\hline Employees & $2(33.3 \%)$ & $3(27.3 \%)$ & $0(0.0 \%)$ & $2(66.7 \%)$ & $7(29 \%)$ \\
\hline Environment & $3(50.0 \%)$ & $4(36.4 \%)$ & $1(25.0 \%)$ & $1(33.3 \%)$ & $9(38 \%)$ \\
\hline Society & $0(0.0 \%)$ & $4(36.4 \%)$ & $2(50.0 \%)$ & $0(0.0 \%)$ & $6(25 \%)$ \\
\hline Technology & $1(4.2 \%)$ & $0(0.0 \%)$ & $1(25.0 \%)$ & $0(0.0 \%)$ & $2(8 \%)$ \\
\hline Total & $6(100 \%)$ & $11(100 \%)$ & $4(100 \%)$ & $3(100 \%)$ & $24(100 \%)$ \\
\hline \multicolumn{6}{|l|}{ Plot line } \\
\hline Customer Satisfaction & $1(16.7 \%)$ & $4(36.4 \%)$ & $1(25.0 \%)$ & $1(33.3 \%)$ & $7(29 \%)$ \\
\hline Energy Efficiency & $3(50.0 \%)$ & $2(18.2 \%)$ & $2(50.0 \%)$ & $0(0.0 \%)$ & $7(29 \%)$ \\
\hline Team Work & $2(33.3 \%)$ & $2(18.2 \%)$ & $0(0.0 \%)$ & $1(33.3 \%)$ & $5(21 \%)$ \\
\hline Green World & $0(0.0 \%)$ & $3(27.3 \%)$ & $1(25.0 \%)$ & $1(33.3 \%)$ & $5(21 \%)$ \\
\hline Total & $6(100 \%)$ & $11(100 \%)$ & $4(100 \%)$ & $3(100 \%)$ & $24(100 \%)$ \\
\hline \multicolumn{6}{|l|}{ Scene } \\
\hline Corporation itself & $2(33.3 \%)$ & $1(9.1 \%)$ & $1(25.0 \%)$ & $1(33.3 \%)$ & $5(21 \%)$ \\
\hline Environment & $1(16.7 \%)$ & $1(9.1 \%)$ & $2(50.0 \%)$ & $0(0.0 \%)$ & $4(17 \%)$ \\
\hline Society & $3(50.0 \%)$ & $9(81.8 \%)$ & $1(25.0 \%)$ & $2(66.7 \%)$ & $15(62 \%)$ \\
\hline Total & $6(100 \%)$ & $11(100 \%)$ & $4(100 \%)$ & $3(100 \%)$ & $24(100 \%)$ \\
\hline \multicolumn{6}{|l|}{ Sanctioning agent } \\
\hline Employee Agent & $0(0.0 \%)$ & $1(9.1 \%)$ & $2(50.0 \%)$ & $0(0.0 \%)$ & $3(12 \%)$ \\
\hline Customer Agent & $1(16.7 \%)$ & $1(9.1 \%)$ & $0(0.0 \%)$ & $1(33.3 \%)$ & $3(12 \%)$ \\
\hline Community Agent & $2(33.3 \%)$ & $2(18.2 \%)$ & $1(25.0 \%)$ & $1(33.3 \%)$ & $6(25 \%)$ \\
\hline General Public Agent & $0(0.0 \%)$ & $2(18.2 \%)$ & $1(25.0 \%)$ & $0(0.0 \%)$ & $3(12 \%)$ \\
\hline Globalization Agent & $3(50.0 \%)$ & $5(45.5 \%)$ & $0(0.0 \%)$ & $1(33.3 \%)$ & $9(39 \%)$ \\
\hline Total & $6(100 \%)$ & $11(100 \%)$ & $4(100 \%)$ & $3(100 \%)$ & $24(100 \%)$ \\
\hline \multicolumn{6}{|l|}{ Master analogues } \\
\hline Righteous & $1(16.7 \%)$ & $6(54.5 \%)$ & $0(0.0 \%)$ & $0(0.0 \%)$ & $7(29 \%)$ \\
\hline Social & $2(33.3 \%)$ & $2(18.2 \%)$ & $3(75.0 \%)$ & $2(66.7 \%)$ & $9(38 \%)$ \\
\hline Pragmatic & $3(50.0 \%)$ & $3(27.3 \%)$ & $1(25.0 \%)$ & $1(33.3 \%)$ & $8(33 \%)$ \\
\hline Total & $6(100 \%)$ & $11(100 \%)$ & $4(100 \%)$ & $3(100 \%)$ & $24(100 \%)$ \\
\hline
\end{tabular}

Source: authors' calculation

\section{Table 6}

Cross-tabulation of Rhetorical vision and Basic and Structural Terms of SCT 


\begin{tabular}{|c|c|c|c|c|}
\hline \multirow[b]{2}{*}{ Taxonomies } & \multicolumn{3}{|c|}{ Rhetorical vision } & \multirow[b]{2}{*}{ Total } \\
\hline & Ethos & Logos & Pathos & \\
\hline \multicolumn{5}{|l|}{ Fantasy Type } \\
\hline Best in Class & $1(12.5 \%)$ & $4(36.4 \%)$ & $1(20.0 \%)$ & $6(25 \%)$ \\
\hline Leader & $5(62.5 \%)$ & $4(36.4 \%)$ & $2(40.0 \%)$ & $11(46 \%)$ \\
\hline Follower & $1(12.5 \%)$ & $2(18.2 \%)$ & $1(20.0 \%)$ & $4(17 \%)$ \\
\hline Starter & $1(12.5 \%)$ & $1(9.1 \%)$ & $1(20.0 \%)$ & $3(12 \%)$ \\
\hline Total & $8(100 \%)$ & $11(100 \%)$ & $5(100 \%)$ & $24(100 \%)$ \\
\hline \multicolumn{5}{|l|}{ Dramatis personae } \\
\hline Employees & $2(25.0 \%)$ & $4(36.4 \%)$ & $1(20.0 \%)$ & $7(29 \%)$ \\
\hline Environment & $3(33.3 \%)$ & $4(36.4 \%)$ & $2(40.0 \%)$ & $9(38 \%)$ \\
\hline Society & $3(37.5 \%)$ & $2(18.2 \%)$ & $1(20.0 \%)$ & $6(25 \%)$ \\
\hline Technology & $0(0.0 \%)$ & $1(9.1 \%)$ & $1(20.0 \%)$ & $2(8 \%)$ \\
\hline Total & $8(100 \%)$ & $11(100 \%)$ & $5(100 \%)$ & $24(100 \%)$ \\
\hline \multicolumn{5}{|l|}{ Plot line } \\
\hline Customer Satisfaction & $2(25.0 \%)$ & $3(27.3 \%)$ & $2(40.0 \%)$ & $7(29 \%)$ \\
\hline Energy Efficiency & $1(12.5 \%)$ & $4(36.4 \%)$ & $2(40.0 \%)$ & $7(29 \%)$ \\
\hline Team Work & $2(25.0 \%)$ & $2(18.2 \%)$ & $1(20.0 \%)$ & $5(21 \%)$ \\
\hline Green World & $3(37.5 \%)$ & $2(18.2 \%)$ & $0(0.0 \%)$ & $5(21 \%)$ \\
\hline Total & $8(100 \%)$ & $11(100 \%)$ & $5(100 \%)$ & $24(100 \%)$ \\
\hline \multicolumn{5}{|l|}{ Scene } \\
\hline Corporation itself & $1(12.5 \%)$ & $4(36.4 \%)$ & $0(0.0 \%)$ & $5(21 \%)$ \\
\hline Environment & $1(12.5 \%)$ & $1(9.1 \%)$ & $2(40.0 \%)$ & $4(17 \%)$ \\
\hline Society & $6(75.0 \%)$ & $6(54.5 \%)$ & $3(60.0 \%)$ & $15(62 \%)$ \\
\hline Total & $8(100 \%)$ & $11(100 \%)$ & $5(100 \%)$ & $24(100 \%)$ \\
\hline \multicolumn{5}{|l|}{ Sanctioning agent } \\
\hline Employee Agent & $2(25.0 \%)$ & $0(0.0 \%)$ & $1(20.0 \%)$ & $3(12 \%)$ \\
\hline Customer Agent & $0(0.0 \%)$ & $3(27.3 \%)$ & $0(0.0 \%)$ & $3(12 \%)$ \\
\hline Community Agent & $1(12.5 \%)$ & $3(27.3 \%)$ & $2(40.0 \%)$ & $6(25 \%)$ \\
\hline General Public Agent & $1(12.5 \%)$ & $2(18.2 \%)$ & $0(0.0 \%)$ & $3(12 \%)$ \\
\hline Globalization Agent & $4(50.0 \%)$ & $3(27.3 \%)$ & $2(40.0 \%)$ & $9(39 \%)$ \\
\hline Total & $8(100 \%)$ & $11(100 \%)$ & $5(100 \%)$ & $24(100 \%)$ \\
\hline \multicolumn{5}{|l|}{ Master analogues } \\
\hline Righteous & $4(50.0 \%)$ & $2(18.2 \%)$ & $1(20.0 \%)$ & $7(29 \%)$ \\
\hline Social & $3(37.5 \%)$ & $4(36.4 \%)$ & $2(40.0 \%)$ & $9(38 \%)$ \\
\hline Pragmatic & $1(12.5 \%)$ & $5(45.5 \%)$ & $2(40.0 \%)$ & $8(33 \%)$ \\
\hline Total & $8(100 \%)$ & $11(100 \%)$ & $5(100 \%)$ & $24(100 \%)$ \\
\hline
\end{tabular}

Source: authors' calculation

Table 7

Cross-Tabulation of Geographical Classification and Basic and Structural Terms of SCT

\begin{tabular}{lllll}
\hline & & \multicolumn{3}{c}{ Geographical Classification } \\
Taxonomies & Asian & European & American & Total \\
\hline Fantasy Type & & & & \\
Best in Class & $1(12.5 \%)$ & $5(83.3 \%)$ & $0(0.0 \%)$ & $6(25 \%)$ \\
Leader & $6(75.0 \%)$ & $0(0.0 \%)$ & $5(50.0 \%)$ & $11(46 \%)$ \\
Follower & $1(12.5 \%)$ & $1(16.7 \%)$ & $2(20.0 \%)$ & $4(17 \%)$ \\
Starter & $0(0.0 \%)$ & $0(0.0 \%)$ & $3(30.0 \%)$ & $3(12 \%)$ \\
$\quad$ Total & $8(100 \%)$ & $6(100 \%)$ & $10(100 \%)$ & $24(100 \%)$ \\
Rhetorical vision & & & &
\end{tabular}




\begin{tabular}{|c|c|c|c|c|}
\hline \multirow[b]{2}{*}{ Taxonomies } & \multicolumn{3}{|c|}{ Geographical Classification } & \multirow[b]{2}{*}{ Total } \\
\hline & Asian & European & American & \\
\hline Ethos & $4(50.0 \%)$ & $0(0.0 \%)$ & $4(40.0 \%)$ & $8(33 \%)$ \\
\hline Logos & $3(37.5 \%)$ & $4(66.7 \%)$ & $4(40.0 \%)$ & $11(46 \%)$ \\
\hline Pathos & $1(12.5 \%)$ & $2(33.3 \%)$ & $2(20.0 \%)$ & $5(21 \%)$ \\
\hline Total & $8(100 \%)$ & $6(100 \%)$ & $10(100 \%)$ & $24(100 \%)$ \\
\hline \multicolumn{5}{|l|}{ Dramatis personae } \\
\hline Employees & $2(25.0 \%)$ & $1(16.7 \%)$ & $4(40.0 \%)$ & $7(29 \%)$ \\
\hline Environment & $2(25.0 \%)$ & $4(66.7 \%)$ & $3(30.0 \%)$ & $9(38 \%)$ \\
\hline Society & $3(37.5 \%)$ & $0(0.0 \%)$ & $3(30.0 \%)$ & $6(25 \%)$ \\
\hline Technology & $1(12.5 \%)$ & $1(16.7 \%)$ & $0(0.0 \%)$ & $2(8 \%)$ \\
\hline Total & $8(100 \%)$ & $6(100 \%)$ & $10(100 \%)$ & $24(100 \%)$ \\
\hline \multicolumn{5}{|l|}{ Plot line } \\
\hline Customer Satisfaction & $1(12.5 \%)$ & $1(16.7 \%)$ & $5(50.0 \%)$ & $7(29 \%)$ \\
\hline Energy Efficiency & $1(12.5 \%)$ & $4(66.7 \%)$ & $2(20.0 \%)$ & $7(29 \%)$ \\
\hline Team Work & $2(25.0 \%)$ & $1(16.7 \%)$ & $2(20.0 \%)$ & $5(21 \%)$ \\
\hline Green World & $4(50.0 \%)$ & $0(0.0 \%)$ & $1(10.0 \%)$ & $5(21 \%)$ \\
\hline Total & $8(100 \%)$ & $6(100 \%)$ & $10(100 \%)$ & $24(100 \%)$ \\
\hline \multicolumn{5}{|l|}{ Scene } \\
\hline Corporation itself & $1(12.5 \%)$ & $2(33.3 \%)$ & $2(20.0 \%)$ & $5(21 \%)$ \\
\hline Environment & $0(0.0 \%)$ & $2(33.3 \%)$ & $2(20.0 \%)$ & $4(17 \%)$ \\
\hline Society & $7(87.5 \%)$ & $2(33.3 \%)$ & $6(60.0 \%)$ & $15(62 \%)$ \\
\hline Total & $8(100 \%)$ & $6(100 \%)$ & $10(100 \%)$ & $24(100 \%)$ \\
\hline \multicolumn{5}{|l|}{ Sanctioning agent } \\
\hline Employee Agent & $1(12.5 \%)$ & $1(16.7 \%)$ & $1(10.0 \%)$ & $3(12 \%)$ \\
\hline Customer Agent & $0(0.0 \%)$ & $1(16.7 \%)$ & $2(20.0 \%)$ & $3(12 \%)$ \\
\hline Community Agent & $2(25.0 \%)$ & $2(33.3 \%)$ & $2(20.0 \%)$ & $6(25 \%)$ \\
\hline General Public Agent & $1(12.5 \%)$ & $0(0.0 \%)$ & $2(20.0 \%)$ & $3(12 \%)$ \\
\hline Globalization Agent & $4(50.0 \%)$ & $2(33.3 \%)$ & $3(30.0 \%)$ & $9(39 \%)$ \\
\hline Total & $8(100 \%)$ & $6(100 \%)$ & $10(100 \%)$ & $24(100 \%)$ \\
\hline \multicolumn{5}{|l|}{ Master analogues } \\
\hline Righteous & $4(50.0 \%)$ & $1(16.7 \%)$ & $2(20.0 \%)$ & $7(29 \%)$ \\
\hline Social & $2(25.0 \%)$ & $2(33.3 \%)$ & $5(50.0 \%)$ & $9(38 \%)$ \\
\hline Pragmatic & $2(25.0 \%)$ & $3(50.0 \%)$ & $3(30.0 \%)$ & $8(33 \%)$ \\
\hline Total & $8(100 \%)$ & $6(100 \%)$ & $10(100 \%)$ & $24(100 \%)$ \\
\hline
\end{tabular}

Source: authors' calculation

Table 8

Breakdown of Aristotle's persuasion and rhetorical strategies and the legitimacy link

\begin{tabular}{|c|c|c|c|c|}
\hline \multirow{2}{*}{} & \multicolumn{4}{|c|}{$\begin{array}{r}\text { Aristotle's persuasion and rhetorical strategies } \\
\text { (based on fantasy type) }\end{array}$} \\
\hline & Ethos & logos & Pathos & Total \\
\hline No of company & $8(33 \%)$ & $11(46 \%)$ & $5(21 \%)$ & $24(100 \%)$ \\
\hline Legitimacy type & Cognitive & Pragmatic & Moral & \\
\hline
\end{tabular}

Source: From Table 5 and Table 6 


\section{Section 6}

\section{Conclusion and future research}

There is considerable focus on the company's sustainability. Therefore, it is significant that how the corporation address the issues and communicate their sustainability through sustainability reports (Sörensson and Jansson 2016). In this case, the audiences of stakeholders use the sustainability reports to formulate a decision by the CEO/BOD (Young 2016). Researchers argue that sustainability reporting is used to satisfy stakeholders and shows accountability and legitimacy. Also, it's a way of communicating with the stakeholders (Sweeney and Coughlan 2008; Sörensson and Jansson 2016). The findings presented here shows how companies' communication goes through rhetoric and persuasion that is being used in their sustainability reports.

The study reveals that most of the sample companies communicate fantasy type, rhetoric vision, dramatic and master analogue in their corporate sustainability reporting. However, the way of communication under SCT is found different from each component and thus we come up with three cross tabulation tables (Table 1, 2 \& 3) for one component against to other SCT taxonomies. In terms of research question one, we found that 'Logos' is the predominant among the sample companies. Out of 24 companies, 11 companies (46\%) adopt 'Logos' rhetorical vision (Table 5). This vision is equally popular with both American and European companies (Table 7), therefore, it can be assumed that companies are likely to discharge pragmatic legitimacy by disclosing logical and rational argument. They aim to enhance reputation and create corporate values in sustainability reporting. On the other hand, American companies also equally adopt the 'Ethos' rhetorical vision similar to Asian companies (Table 7). However, there is a contrast between American and European companies in terms of 'Ethos'. It can be observed that no European company communicate any 'Ethos' in the reporting (Table 7), hence both American and Asian companies adopt 'Ethos' rhetorical vision predominantly in their sustainability reports and are likely to discharge cognitive legitimacy by accepting CSR norm/standards. In this way, they aim to enhance reputation and create corporate accountability. In all the three regions, 'Pathos' is presence in the reporting $(n=5)$, so we can assume that companies use emotional languages or metaphors as communication to liberate moral legitimacy. It is also noted that the distributions of 
'Ethos', 'Logos' and 'Pathos' are found in all the fantasy type categories, but 'Logos' has occupied highest percentage $(46 \%, n=11)$. Consequently, we can assume that majority companies are keen to discharge pragmatic legitimacy by disclosing logical and rational argument in their sustainability reporting to communicate their participation in the global social and environmental issues.

With regard to persuasion styles in the sustainability reporting (research question 2) within the framework of SCT, the study reveals that most of the companies have different actors or moderators of the taxonomies of SCT components. Under fantasy types, 11 companies fall in the 'Leader' category followed by six in 'Best in class' categories. This indicates that company's addresses CSR importance by creating CSR management system, adopting any global standard and performing CSR in respect of social, economic and environmental issues. It is also revealed that nine companies use 'environment' as dramatic personae followed by 'employees' $(n=7)$ and society $(n=6)$. Given the prominence of CSR and sustainability, companies use these three personae 'environment', 'employee' and 'society' but only two companies report 'technology' as personae in the vision stage. It implies that companies have used different actors as persuasion in the sustainability reporting. In the plot line, both 'customer satisfaction' and 'energy efficiency' taxonomies appeared highest in total number of companies $(n=14)$ which acknowledges companies' agenda \& action aligns with the components of CSR. Interestingly in the scene, 'society' role is played predominantly by the maximum companies $(n=15)$. Therefore, it is understood that companies are active and willing to show their social activities at schools, charitable institutes, and technology innovation. From the outcomes of 'sanctioning agent', we can see that 'Globalising agent' is working as justification and representing agent of the rhetorical vision by the maximum number of companies $(n=9)$ under the sample. It accomplishes that most of the companies are world class and internationally recognised in terms of their nature of business. We have also found that master analogues of the corporate sustainability reporting embedded across all the fantasy types. It is seen that social master analogue $(n=9)$ is dominant among all categories of fantasy type. It means that companies are communicating by emphasizing primarily on human relations such as trust, caring, family ties and humaneness. On the other hand, pragmatic master analogues (50\%) appear most in the 'Best in class' fantasy type. So, it indicates that companies are concerned for heightens expediency, utility, efficiency and cost effectiveness. While righteous master analogue is the dominant in the 'Leader' 
fantasy type, we may assume that companies communicate their stresses in the correct way by considering what right and wrong, moral and immoral etc. is.

From the above discussions, we conclude that SCT has a capacity as a theoretical and analytical framework for exploring corporate messages disclosed in the online corporate sustainability reporting. We explored the sustainability reporting's rhetoric and persuasion used by the companies in a different platform/frame work which might be interested to the academic scholars in order to understand the CSR communication theme in a new dimension. In short, we contribute by exploring reporting communication in the lens of SCT and provide a seed for further research in other likewise avenues.

\section{Limitations of the study and future research}

There are some limitations to this research. Firstly, the study considers SCT as a research framework, however, we do not consider symbolic clue and saga as coders do not found or identified sufficient theme in sustainability reporting. Secondly, we focused on whole sustainability reporting and thus it can be interpreted in different ways including generalising communication style of the sample companies. Further research can be done in the rhetoric of other parts of corporate web pages like director report and mission statement.

Ethical approval: This article does not contain any studies with human participants performed by any of the authors. 


\section{References:}

Abizadeh, A. (2002). The passions of the wise:" Phronêsis", rhetoric, and Aristotle's passionate practical deliberation. The Review of Metaphysics, 267-296.

Aerts, W. (1994). On the use of accounting logic as an explanatory category in narrative accounting disclosures. Accounting, Organizations and Society, 19(4-5), 337-353.

Aerts, W. (2001). Inertia in the attributional content of annual accounting narratives. European accounting review, 10(1), 3-32.

Aldrich, H. E., \& Fiol, C. M. 1994. Fools rush in? The institutional context of industry creation. Academy of Management Review, 19(4), 645-670.

Alvesson, M. (1993). Organizations as rhetoric: Knowledge-intensive firms and the struggle with ambiguity. Journal of Management studies, 30(6), 997-1015.

Amernic, J. H. (1996). The rhetoric versus the reality, or is the reality "mere" rhetoric? a case study of public accounting firms' responses to a company's invitation for alternative opinions on an accounting matter. Critical Perspectives on Accounting, 7(1), 57-75.

Aristotle. (1991). The art of rhetoric. New York, NY: Penguin books.

Arrington, C. E., \& Schweiker, W. (1992). The rhetoric and rationality of accounting research. Accounting, Organizations and Society, 17(6), 511-533.

Arvidsson, S. (2009), "Non-financial information and the annual report", working paper, Department of Business Administration, Lund University, Lund.

Ashforth, B. E., \& Gibbs, B. W. (1990). The double-edge of organizational legitimation. Organization science, 1(2), 177-194.

Azizul Islam, M., \& Deegan, C. (2008). Motivations for an organisation within a developing country to report social responsibility information: Evidence from Bangladesh. Accounting, Auditing \& Accountability Journal, 21(6), 850-874.

Banerjee, S. B. (2008). Corporate social responsibility: The good, the bad and the ugly. Critical sociology, 34(1), 51-79.

Bazerman, C. (1994). Constructing experience. Carbondale: Southern Illinois University Press.

Berg, B. (2004), Qualitative Research Methods for the Social Science, Allyn and Bacon, Toronto.

Bhatia, V. K. (1993). Analysing genre: language use in professional settings. London, England: Longman.

Bhatia, V. K. (2004). Worlds of written discourse: A genre-based view. London, England: Continuum.

Billig, M. (1987). Arguing and thinking: A rhetorical approach to social psychology. Cambridge, England: Cambridge University Press.

Blumer, H. (1954). What is wrong with social theory? American Sociological Review, 18, 3-10.

Böhling, K., Murguía, D. I., \& Godfrid, J. (2017). Sustainability Reporting in the Mining Sector: Exploring Its Symbolic Nature. Business \& Society, 
Bormann, E. G. (1972). Fantasy and rhetorical vision: The rhetorical criticism of social reality. Quarterly journal of speech, 58(4), 396-407.

Bormann, E. G. (1980). Communication theory. New York: Holt, Rhinehart and Winston Bormann, E. G. (1982). I. Fantasy and rhetorical vision: Ten years later. Quarterly Journal of Speech, 68(3), 288-305.

Bormann, E. G. (1983). Symbolic convergence: Organizational communication and culture. In L. L. Putnam \& M. E. Pacanowsky (Eds.), Communication and organizations: An interpretive approach (pp. 99-122). Beverly Hills, CA: Sage.

Bormann, E. G. (1985a). Symbolic convergence theory: A communication formulation. Journal of communication, 35(4), 128-138.

Bormann, E. G. (1985b). The force of fantasy: Restoring the America dream. Carbondale, IL: Southern Illinois University Press.

Bormann, E. G., Cragan, J. F., \& Shields, D. C. (2001). Three decades of developing, grounding, and using symbolic convergence theory (SCT). Annals of the International Communication Association, 25(1), 271-313.

Bostdorff, D., \& Vibbert, S. L. (1994). Values advocacy: Enhancing organizational images, deflecting public criticism, and grounding future arguments. Public Relations Review, 20, 141-158.

Bostdorff, D. M. (1992). "The decision is yours" campaign: Planned Parenthood's characteristic argument of moral virtue. In E. L. Toth \& R. L. Heath (Eds.), Rhetorical and critical approaches to public relations (pp. 301-314). Hillsdale, NJ: Lawrence Erlbaum.

Boyd, J., \& Waymer, D. (2011). Organizational rhetoric: A subject of interest (s). Management Communication Quarterly, 25(3), 474-493.

Braet, A. C. (1992). Ethos, pathos and logos in Aristotle's Rhetoric: A re-examination. Argumentation, 6(3), 307-320.

Brennan, N., \& Gray, S. J. (2000). Rhetoric and argument in financial reporting. The Association of Chartered Certified Accountants.

Brennan, M. N., \& M. Merkl-Davies, D. M (2014). Rhetoric and argument in social and environmental reporting: the Dirty Laundry case. Accounting, Auditing \& Accountability Journal, 27(4), 602-633.

Brønn, P. S., \& Vidaver-Cohen, D. (2009). Corporate motives for social initiative: legitimacy, sustainability, or the bottom line?. Journal of Business Ethics, 87, 91-109.

Bullis, C. (1997). Business communication and the natural environment: Using traditional and contemporary perspectives to understand the connections. The Journal of Business Communication (1973), 34(4), 455-477.

Burke, K. (1969). A rhetoric of motives (Vol. 111). Univ of California Press.

Burke, R. J. (1982). Politics as rhetoric. Ethics, 93(1), 45-55.

Burr V. (1995). An introduction to social constructionism. London: Routledge.

Campbell, J. L. (2007). Why would corporations behave in socially responsible ways? An institutional theory of corporate social responsibility. Academy of management Review, 32(3), 946-967.

Carroll, A. B. (1979). A three-dimensional conceptual model of corporate performance. Academy of management review, 4(4), 497-505. 
Carroll, A. B. (1991). The pyramid of corporate social responsibility: Toward the moral management of organizational stakeholders. Business horizons, 34(4), 39-48.

Carroll, A. B. (1998). The four faces of corporate citizenship. Business and society review, 100(1), 17.

Carroll, A. B. (1999). Corporate social responsibility: Evolution of a definitional construct. Business \& society, 38(3), 268-295.

Castelló, I., \& Lozano, J. M. (2011). Searching for new forms of legitimacy through corporate responsibility rhetoric. Journal of Business Ethics, 100(1), 11-29.

Charmaz, K. (2003). Grounded theory: Objectivist and constructivist methods. In N. K. Denzin \& Y. S. Lincoln (Eds.), Strategies for qualitative inquiry (2nd ed., pp. 249-291). Thousand Oaks, CA: Sage.

Chen, J., Huang, Q., Peng, H., \& Zhong, H. (2015). Research report on corporate social responsibility of China. Berlin: Springer.

Chalaby J. 1996. Beyond the prison-house of language: discourse as a sociological concept. The British Journal of Sociology 47(4): 684-698.

Cheney, G., Christensen, L. T., Conrad, C., \& Lair, D. J. (2004). Corporate rhetoric as organizational discourse. The Sage handbook of organizational discourse, 79-103.

Clatworthy, M. A., \& Jones, M. J. (2006). Differential patterns of textual characteristics and company performance in the chairman's statement. Accounting, Auditing \& Accountability Journal, 19(4), 493-511.

Cohen, J. (1960). A coefficient of agreement for nominal scales. Educational and psychological measurement, 20(1), 37-46.

Coombs, W. T. \& Holladay, S. J. (2013). The pseudo-panopticon: the illusion created by CSR-related transparency and the internet. Corporate Communications: An International Journal, 18(2), 212-227.

Cox, R. (2012). Environmental communication and the public sphere. Sage publications.

Cragan, J. F., \& Shields, D. C. (1981). Applied communication research: A dramatistic approach. Prospect Heights, IL: Waveland Press.

Cragan, J. F., \& Shields, D. C. (1981). Applied Communication Research a Dramatistic Approach.

Cragan, J. F., \& Shields, D. C. (1992). The use of symbolic convergence theory in corporate strategic planning: A case study. Journal of Applied Communication Research, 20(2), 199-218.

Cragan, J. F., \& Shields, D. C. (1995). Symbolic theories in applied communication research: Bormann, Burke, and Fisher. Cresskill, NJ: Hampton Press.

Crane, A., \& Glozer, S. (2016). Researching corporate social responsibility communication: themes, opportunities and challenges. Journal of Management Studies, 53(7), 1223-1252.

Cross, M. (1991). Aristotle and business writing: Why we need to teach persuasion. The Bulletin of the Association for Business Communication, 54(1), 3-6.

Crossan, M. M., Lane, H. W., \& White, R. E. (1999). An organizational learning framework: From intuition to institution. Academy of Management Review, 24(3), 522-537.

Davison, J. (2014). Visual rhetoric and the case of intellectual capital. Accounting, Organizations and Society, 39(1), 20-37.

Devin, B. L., \& Lane, A. B. (2014). Communicating engagement in corporate social responsibility: A meta-level construal of engagement. Journal of Public Relations Research, 26(5), 436-454. 
Dey, C. (2007). Social accounting at Traidcraft plc: A struggle for the meaning of fair trade. Accounting, Auditing \& Accountability Journal, 20(3), 423-445.

Díez-Martín, F., Prado-Roman, C., \& Blanco-González, A. (2013). Beyond legitimacy: legitimacy types and organizational success. Management Decision, 51(10), 1954-1969.

Dong, S., \& Xu, L. (2016). The impact of explicit CSR regulation: evidence from China's mining firms. Journal of Applied Accounting Research, 17(2), 237-258.

Drumheller, K. (2005). Millennial dogma: A fantasy theme analysis of the millennial generation's uses and gratifications of religious content media. Journal of Communication \& Religion, 28, 47-70.

Du, S., Bhattacharya, C. B., \& Sen, S. (2010). Maximizing business returns to corporate social responsibility (CSR): The role of CSR communication. International Journal of Management Reviews, 12(1), 8-19.

Duffy, M. E. (2003). Web of hate: A fantasy theme analysis of the rhetorical vision of hate groups online. Journal of Communication Inquiry, 27(3), 291-312.

Endres, T. G. (1994). Co-existing master analogues in symbolic convergence theory: The Knights of Columbus quincentennial campaign. Communication Studies, 45(3-4), 294-308.

Estava, D. J. (2012). Lope de Aguirre, the tyrant, and the prince: Convergence and divergence in postcolonial collective memory. Journal of International and Intercultural Communication, 5(4), 291308.

Finnemore, M., \& Sikkink, K. (1998). International norm dynamics and political change. International organization, 52(4), 887-917.

Finnemore, M. (1996). Norms, culture, and world politics: insights from sociology's institutionalism, international Organization, 50(2), 325-347.

Foss, S. K. (1989). Generic criticism. In S. K. Foss (Ed.), Rhetorical criticism: Exploration and practice. Prospect Heights, IL: Waveland.

Gamson, W. A., \& Modigliani, A. (1989). Media discourse and public opinion on nuclear power: A constructionist approach. American journal of sociology, 95(1), 1-37.

Garver, E. (1994). Aristotle's Rhetoric: An art of character. University of Chicago Press.

Glaser, B. G. (1978). Theoretical sensitivity: Advances in the methodology of grounded theory. Mill Valley, CA: Sociology Press.

Goetz, J \& LeCompte, M (1984). Ethnography and qualitative designs in educational research. San Diego, CA: Academic Press.

Golob, U., \& Podnar, K. (2014). Critical points of CSR-related stakeholder dialogue in practice. Business Ethics: A European Review, 23(3), 248-257.

Gray, R., Owen, D., \& Adams, C. (1996). Accounting \& accountability: changes and challenges in corporate social and environmental reporting. Prentice Hall.

Gray, R., Kouhy, R., \& Lavers, S. (1995). Corporate social and environmental reporting: a review of the literature and a longitudinal study of UK disclosure. Accounting, Auditing \& Accountability Journal, $8(2), 47-77$.

Gray, R., Owen, D., \& Maunders, K. (1988). Corporate social reporting: emerging trends in accountability and the social contract. Accounting, Auditing \& Accountability Journal, 1(1), 6-20. 
Global Reporting Initiative (GRI). 2016. "Consolidated set of GRI sustainability reporting standards 2016, access on 7 December https://www.globalreporting.org/standards/gri-standards-downloadcenter/

Griffin, J. J., \& Mahon, J. F. (1997). The corporate social performance and corporate financial performance debate: Twenty-five years of incomparable research. Business \& society, 36(1), 5-31. Guthrie, J., \& Parker, L. D. (1989). Corporate social reporting: a rebuttal of legitimacy theory. Accounting and business research, 19(76), 343-352.

Guthrie, J., Petty, R., Yongvanich, K., \& Ricceri, F. (2004). Using content analysis as a research method to inquire into intellectual capital reporting. Journal of intellectual capital, 5(2), 282-293.

Gyimóthy, S. (2013). Symbolic convergence and tourism social media. In Tourism Social Media: Transformations in Identity, Community and Culture (pp. 55-71). Emerald Group Publishing Limited.

Hartman, L. P., Rubin, R. S., \& Dhanda, K. K. (2007). The communication of corporate social responsibility: United States and European Union multinational corporations. Journal of Business Ethics, 74(4), 373-389.

Hayes, A. F., \& Krippendorff, K. (2007). Answering the call for a standard reliability measure for coding data. Communication methods and measures, 1(1), 77-89.

Heath, R. L. (2001). Chapter 2: a rhetorical enactment rationale for public relations: the good organization communicating well. In R. L. Heath (Ed.), Handbook of public relations (pp. 31-50). Thousand Oaks, CA: Sage.

Heath, R. L. (1993). A rhetorical approach to zones of meaning and organizational prerogatives. Public Relations Review, 19(2), 141-155.

Henrik, J. (2005). The history and theory of rhetoric: an introduction, $3^{\text {rd }}$ ed. Pearson Education, Boston.

Higgins, C. and Robyn W. (2012). Ethos, logos, pathos: Strategies of persuasion in social/environmental reports. Accounting Forum. 36 (3), pp. 194-208.

Hooper, K., \& Pratt, M. (1995). Discourse and rhetoric: the case of the New Zealand Native Land Company. Accounting, Auditing \& Accountability Journal, 8(1), 10-37.

Hopkins, L. (2011). Symbolic convergence theory. Retrieved October 14, 2014. from http://www.leehopkins.net/2011/05/31/symbolic-convergence-theoryl.

Ihlen, Ø. (2008). Mapping the environment for corporate social responsibility: Stakeholders, publics and the public sphere. Corporate Communications: An International Journal, 13(2), 135-146.

Ihlen, Ø. (2009a). Business and climate change: the climate response of the world's 30 largest corporations. Environmental Communication, 3(2), 244-262.

Ihlen, Ø., Van Ruler, B., \& Fredriksson, M. (Eds.). (2009b). Public relations and social theory: Key figures and concepts. Routledge.

Ihlen, $\varnothing$. (2011). Rhetoric and corporate social responsibility. Handbook of communication and corporate social responsibility, 147-166.

Ihlen, Ø., Bartlett, J., \& May, S. (Eds.). (2011). The handbook of communication and corporate social responsibility. John Wiley \& Sons.

Johansen, T. S., \& Nielsen, A. E. (2011). Strategic stakeholder dialogues: A discursive perspective on relationship building. Corporate Communications: An International Journal, 16(3), $204-217$.

Jonker, J. (2005). CSR Wonderland: navigating between movement, community and organisation. The Journal of Corporate Citizenship, (20), 19-22. 
Jose, A., \& Lee, S. M. (2007). Environmental reporting of global corporations: A content analysis based on website disclosures. Journal of Business Ethics, 72(4), 307-321.

Kartikawangi, D. (2017). Symbolic convergence of local wisdom in cross-cultural collaborative social responsibility: Indonesian case. Public Relations Review, 43(1), 35-45.

Kennedy, G.A. (1991), Aristotle on Rhetoric: A Theory of Civic Discourse, Oxford University Press, Oxford

Khan, M., Serafeim, G., \& Yoon, A. (2016). Corporate sustainability: First evidence on materiality. The Accounting Review, 91(6), 1697-1724.

Kiliç, M. (2016). Online corporate social responsibility (CSR) disclosure in the banking industry: Evidence from Turkey. International Journal of Bank Marketing, 34(4), 550-569.

Klotz, A. (1999). Norms in international relations: The struggle against apartheid. Cornell University Press.

Krippendorff, K. (1980). Content analysis. Beverly Hills. California: Sage Publications, 7, I-84.

Laine, M. (2005). Meanings of the term 'sustainable development 'in Finnish corporate disclosures. In Accounting Forum, 29(4), 395-413).

Laine, M. (2010). Towards sustaining the status quo: Business talk of sustainability in Finnish corporate disclosures 1987-2005. European Accounting Review, 19(2), 247-274.

Laine M. (2009). Ensuring legitimacy through rhetorical changes? A longitudinal interpretation of the environmental disclosures of a leading Finnish chemical company. Accounting, Auditing \& Accountability Journal 2009, 22(7); 1029-54.

Lee, M. D. P. (2008). A review of the theories of corporate social responsibility: Its evolutionary path and the road ahead. International journal of management reviews, 10(1), 53-73.

Levina, N., \& Orlikowski, W. J. (2009). Understanding shifting power relations within and across organizations: A critical genre analysis. Academy of Management Journal, 52(4), 672-703.

Lewis, S. (2003). Reputation and corporate responsibility. Journal of Communication Management, 7(4), 356-366.

Livesey, S. M. (2002). The discourse of the middle ground: Citizen Shell commits to sustainable development. Management Communication Quarterly, 15(3), 313-349.

Livesey, S. M., \& Graham, J. (2007). Greening of corporations? Eco-talk and the emerging social imaginary. In S. K. May, G. Cheney \& J. Roper (Eds.), The debate over corporate social responsibility (pp. 336-350). New York: Oxford University Press.

Llewellyn, J. (1990). The rhetoric of corporate legitimation: Public relations and philanthropy as social responsibility. Austin, TX: The University of Texas at Austin.

Lozano, R., \& Huisingh, D. (2011). Inter-linking issues and dimensions in sustainability reporting. Journal of Cleaner Production, 19(2), 99-107.

Maignan, I., \& Ralston, D. A. (2002). Corporate social responsibility in Europe and the US: Insights from businesses' self-presentations. Journal of International Business Studies, 33(3), 497-514.

Manetti, G., \& Bellucci, M. (2016). The use of social media for engaging stakeholders in sustainability reporting. Accounting, Auditing \& Accountability Journal, 29(6), 985-1011.

Marais, M. (2012). CEO rhetorical strategies for corporate social responsibility (CSR). Society and business review, 7(3), 223-243. 
Mäkelä, H., \& Laine, M. (2011). A CEO with many messages: Comparing the ideological representations provided by different corporate reports. In Accounting Forum, 35 (4), pp. 217-231.

Masocha, W., \& Weetman, P. (2007). Rhetoric in standard setting: the case of the going-concern audit. Accounting, Auditing \& Accountability Journal, 20(1), 74-100.

Mason, M., \& Mason, R. D. (2012). Communicating a green corporate perspective: Ideological persuasion in the corporate environmental report. Journal of Business and Technical Communication, 26(4), 479-506.

Matten, D., \& Moon, J. (2008). "Implicit" and "explicit" CSR: A conceptual framework for a comparative understanding of corporate social responsibility. Academy of Management Review, 33(2), 404-424.

May, S. K., \& Zorn, T. E. (2003). Forum introduction. Management communication quarterly, 16(4), 595-598.

Merkl-Davies, D. M., Merkl-Davies, D. M., Brennan, N. M., \& Brennan, N. M. (2017). A theoretical framework of external accounting communication: Research perspectives, traditions, and theories. Accounting, Auditing \& Accountability Journal, 30(2), 433-469.

Mezias, S. J. (1990). An institutional model of organizational practice: Financial reporting at the Fortune 200. Administrative science quarterly, 431-457.

McCloskey, D. N. (1998). The rhetoric of economics. University of Wisconsin Press, USA.

Michelon, G., Pilonato, S., \& Ricceri, F. (2015). CSR reporting practices and the quality of disclosure: An empirical analysis. Critical Perspectives on Accounting, 33, 59-78.

Miles, M. B., \& Huberman, A. M. (1994). Qualitative data analysis: An expanded sourcebook. sage.

Milne, M. J., Kearins, K., \& Walton, S. (2006). Creating adventures in wonderland: The journey metaphor and environmental sustainability. Organization, 13(6), 801-839.

Morhardt, J. E. (2010). Corporate social responsibility and sustainability reporting on the internet. Business strategy and the environment, 19(7), 436-452.

Nichols, M. P. (1987). Aristotle's defense of rhetoric. The Journal of Politics, 49(3), 657-677.

Neilsen, E. H., \& Rao, M. H. (1987). The strategy-legitimacy nexus: A thick description. Academy of Management Review, 12(3), 523-533.

Neumann, W. (2003), Social Research Methods: Qualitative and Quantitative Approaches, Allyn \& Bacon, Boston, MA.

Nichols, M. P. (1987). Aristotle's defense of rhetoric. The Journal of Politics, 49(3), 657-677.

Nyberg, D., \& Wright, C. (2012). Justifying business responses to climate change: discursive strategies of similarity and difference. Environment and Planning A, 44(8), 1819-1835.

O'Connor, A., \& Shumate, M. (2010). An economic industry and institutional level of analysis of corporate social responsibility communication. Management Communication Quarterly, 24(4), 529551.

Onkila, T. J. (2009). Corporate argumentation for acceptability: Reflections of environmental values and stakeholder relations in corporate environmental statements. Journal of Business Ethics, 87(2), 285-298. 
Padgett, D.K. (2004). Coming of age: Theoretical thinking, social responsibility, and a global perspective on qualitative research. In D.K. Padgett (Ed.), The qualitative research experience (pp. 297-315). Belmont, CA: Wadsworth/Thompson Learning.

Palenchar, M. J., \& Heath, R. L. (2002). Another part of the risk communication model: Analysis of communication processes and message content. Journal of Public Relations Research, 14(2), 127158.

Park, J., Lee, H., \& Hong, H. (2016). The Analysis of Self-Presentation of Fortune 500 Corporations in Corporate Web Sites. Business \& Society, 55(5), 706-737.

Parsons, T. (1960). Structure and process in modern societies. Glencoe, IL: Free Press.

Patton, M. Q. (2002). Qualitative research and evaluation methods (3rd ed.).Thousand Oaks, CA: Sage.

Payne, R. A. (2001). Persuasion, frames and norm construction. European journal of international relations, 7(1), 37-61.

Perelman, C. (1982). The realm of rhetoric (W. kluback, trans) Notre Dame, IN: the University of Notre dame Press.

Phillips, N.,\& Hardy, C. (2002). Discourse analysis: Investigating processes of social construction. Sage University Papers Series on Qualitative Research Methods: Vol. 50. Thousand Oaks, CA: Sage.

Pinto, I., \& Picoto, W. N. (2016). Configurational analysis of firms' performance: Understanding the role of Internet financial reporting. Journal of Business Research, 69(11), 5360-5365.

Potter, J. (1996). Representing reality: Discourse, rhetoric and social construction. Sage.

Prentice, S. J. (2006). A symbolic convergence theory approach to graduate recruiting. Master of Arts thesis, Texas tech university, USA.

Preuss, L. (2005). Rhetoric and reality of corporate greening: a view from the supply chain management function. Business Strategy and the Environment, 14(2), 123-139.

Putnam, L. (2004). Dialectical and rhetorical tropes in negotiations. Organization Studies, 25, 35-53.

Putnam, L. L., \& Nicotera, A. M. (Eds.). (2009). Building theories of organization: The constitutive role of communication. Routledge.

Putnam, L., \& Pacanowsky, M. E. (1983). Communication and organizations, an interpretive approach (Vol. 65). Sage Publications, Inc.

Ramus, C. A. (2002). Encouraging innovative environmental actions: What companies and managers must do. Journal of World business, 37(2), 151-164.

Roberts, R. W. (1992). Determinants of corporate social responsibility disclosure: An application of stakeholder theory. Accounting, organizations and society, 17(6), 595-612.

Robinson, D. N. (2006). Rhetoric and character in Aristotle. The Review of Metaphysics, 3-15.

Rodríguez Bolívar, M. P. (2009). Evaluating corporate environmental reporting on the internet: the utility and resource industries in Spain. Business \& Society, 48(2), 179-205.

Rolland, D., \& O'Keefe Bazzoni, J. (2009). Greening corporate identity: CSR online corporate identity reporting. Corporate Communications: An International Journal, 14(3), 249-263.

Ruebottom, T. (2013). The microstructures of rhetorical strategy in social entrepreneurship: Building legitimacy through heroes and villains. Journal of Business Venturing, 28(1), 98-116. 
Scherer, A. G., \& Palazzo, G. (2007). Toward a political conception of corporate responsibility: Business and society seen from a Habermasian perspective. Academy of management review, 32(4), 1096-1120.

Scott, W. A. (1955). Reliability of content analysis: The case of nominal scale coding. Public opinion quarterly, 321-325.

Self, L. S. (1979). Rhetoric and phronesis: The Aristotelian ideal. Philosophy \& Rhetoric, 130-145.

Sen, S., \& Cowley, J. (2013). The relevance of stakeholder theory and social capital theory in the context of CSR in SMEs: An Australian perspective. Journal of Business Ethics, 118(2), 413-427.

Shields, D. C. (2000). Symbolic convergence and special communication theories: Sensing and examining dis/enchantment with the theoretical robustness of critical auto ethnography. Communications Monographs, 67(4), 392-421.

Shields, D. C., \& Preston, C. T. (1985). Fantasy theme analysis in competitive rhetorical criticism. National Forensic Journal, 3(2), 102-115.

Smith, A. (2003). Community relations: How an entire industry can change its image through proactive local communications. Journal of Communication Management, 7(3), 254-265.

Sörensson, A., \& Jansson, A. M. (2016). Sustainability reporting among Swedish tourism service providers: information differences between them. WIT Transactions on Ecology and the Environment, $201,103-113$.

Sovacool, B. K., \& Ramana, M. V. (2015). Back to the future: small modular reactors, nuclear fantasies, and symbolic convergence. Science, Technology, \& Human Values, 40(1), 96-125.

Spence, L. J. (2007). CSR and small business in a European policy context: the five "C" s of CSR and small business research agenda 2007. Business and society review, 112(4), 533-552.

Spence, C. (2009). Social accounting's emancipatory potential: A Gramscian critique. Critical Perspectives on Accounting, 20(2), 205-227.

Spence, C., \& Thomson, I. (2009). Resonance tropes in corporate philanthropy discourse. Business Ethics: A European Review, 18(4), 372-388.

Swales, J. M. (1990). Genre analysis: English in academic and research settings. Cambridge, UK: Cambridge University Press.

Stallworth Williams, L. (2008). The mission statement: A corporate reporting tool with a past, present, and future. The Journal of Business Communication (1973), 45(2), 94-119.

Stone, J. F. (2002). Using symbolic convergence theory to discern and segment motives for enrolling in professional master's degree programs. Communication Quarterly, 50(2), 227-243.

Swales, J. M., \& Rogers, P. S. (1995). Discourse and the projection of corporate culture: The mission statement. Discourse \& Society, 6(2), 223-242.

Suchman, M. C. (1995). Managing legitimacy: Strategic and institutional approaches. Academy of management review, 20(3), 571-610.

Sweeney, L., \& Coughlan, J. (2008). Do different industries report corporate social responsibility differently? An investigation through the lens of stakeholder theory. Journal of Marketing Communications, 14(2), 113-124.

Taylor, J. R., \& Van Every, E. J. (2000). The emergent organization. Communication as its site and surface. Mahwah, $\mathrm{NJ}$ : Lawrence Erlbaum Associates. 
Tregidga, H., \& Milne, M. J. (2006). From sustainable management to sustainable development: a longitudinal analysis of a leading New Zealand environmental reporter. Business Strategy and the Environment, 15(4), 219-241.

Tregidga, H., Milne, M., \& Kearins, K. (2014). (Re) presenting 'sustainable organizations'. Accounting, Organizations and Society, 39(6), 477-494.

Trittin, H., \& Schoeneborn, D. (2017). Diversity as polyphony: Reconceptualizing diversity Management from a communication-centered perspective. Journal of Business Ethics, 144(2), 305322.

Unerman, J. (2000). Methodological issues-Reflections on quantification in corporate social reporting content analysis. Accounting, Auditing \& Accountability Journal, 13(5), 667-681.

Van den Hoonard, Will C. (1997), Working with Sensitizing Concepts: Analytical Field Research, Thousand Oaks, CA: Sage Publications.

Wæraas, A., \& Ihlen, Ø. (2009). Green legitimation: the construction of an environmental ethos. International Journal of Organizational Analysis, 17(2), 84-102.

Warnock, K. (1992). Structure and argument in accounting standards. Accounting and Business Research, 22(86), 179-188.

Watson, T. J. (1995). Rhetoric, discourse and argument in organizational sense making: A reflexive tale. Organization Studies, 16, 805-821.

Weick, K. E. (1979). Cognitive processes in organizations. Research in organizational behavior, 1(1), 41-74.

Wood, D. J. (1991). Corporate social performance revisited. Academy of Management Review, 16(4), 691-718.

Young, R. O. (2016). Persuasive Communication: How Audiences Decide. Routledge.

Young, J. J. (2003). Constructing, persuading and silencing: the rhetoric of accounting standards. Accounting, Organizations and Society, 28(6), 621-638.

Zanin, A. C., Hoelscher, C. S., \& Kramer, M. W. (2016). Extending Symbolic Convergence Theory: A Shared Identity Perspective of a Team's Culture. Small Group Research, 47(4), 438-472.

Zenisek, T. J. 1979. Corporate social responsibility: A conceptualization based on organiza-tional literature. Academy of Management Review, 4: 359-368

Appendix 1

Breakdown of industry classification as per geographical location

\begin{tabular}{|l|c|c|c|c|c|c|c|c|}
\hline & $\begin{array}{c}\text { Petroleu } \\
\mathbf{m}\end{array}$ & $\begin{array}{c}\text { Automobile } \\
\mathbf{s}\end{array}$ & Technology & Financial & $\begin{array}{c}\text { Tele- } \\
\text { communications }\end{array}$ & $\begin{array}{c}\text { Electronic } \\
\mathbf{s}\end{array}$ & Others $^{*}$ & Total \\
\hline American & $\mathbf{1}$ & $\mathbf{0}$ & $\mathbf{1}$ & $\mathbf{1}$ & $\mathbf{1}$ & $\mathbf{1}$ & $\mathbf{5}$ & $\mathbf{1 0}$ \\
\hline Asian & $\mathbf{2}$ & $\mathbf{1}$ & $\mathbf{1}$ & $\mathbf{1}$ & $\mathbf{0}$ & $\mathbf{1}$ & $\mathbf{2}$ & 8 \\
\hline $\begin{array}{l}\text { Europea } \\
\mathrm{n}\end{array}$ & $\mathbf{2}$ & $\mathbf{1}$ & $\mathbf{0}$ & $\mathbf{1}$ & $\mathbf{0}$ & $\mathbf{1}$ & $\mathbf{1}$ & 6 \\
\hline & 5 & 2 & 2 & 3 & 1 & 3 & 8 & 24 \\
\hline & & & & & & & & \\
\hline
\end{tabular}

${ }^{*}$ Others include retail, power, pharmaceuticals, motor and food \& heath industry. 
Appendix 2

Coding and measurement procedure of the Fantasy type

\begin{tabular}{|c|c|c|c|c|c|c|c|c|c|}
\hline Key theme/characteristics & Descriptions & \multicolumn{4}{|c|}{ Points allocated } & \multicolumn{4}{|c|}{ Points achieved } \\
\hline & & 1 & 1 & $\mathrm{I}$ & 1 & 4 & 3 & 2 & I \\
\hline $\begin{array}{l}\text { Reporting practice: These disclosures give } \\
\text { an overview of the process that an } \\
\text { organization has followed to define the } \\
\text { content of its sustainability report. } \\
\text { Sustainability/sustainability development: } \\
\text { The effect an organization has on the } \\
\text { economy, the environment, and/or } \\
\text { society, which in turn can indicate its } \\
\text { contribution (positive or negative) to } \\
\text { sustainable development. } \\
\text { Good Governance and employability: } \\
\text { The disclosure of corporate governance } \\
\text { and its related matters best practice for } \\
\text { the company. } \\
\text { Philanthropy: The disclosure on company's } \\
\text { charitable giving strategy and the } \\
\text { Company's social, community and } \\
\text { sustainability initiatives. }\end{array}$ & $\begin{array}{l}\text { GRI Standards; GRI content index; } \\
\text { External assurance; IPIECA } \\
\text { Three dimensions: economic, } \\
\text { environmental and social, } \\
\text { disclosures about an organization's } \\
\text { management approach on material } \\
\text { topics such as economic, } \\
\text { environmental and social (water, } \\
\text { employment), climate change, } \\
\text { greenhouse gas emission. } \\
\text { Corporate governance guidelines, } \\
\text { ownership and legal form, board } \\
\text { independence, information on } \\
\text { employees and other workers, } \\
\text { union activities, information on } \\
\text { memberships of industry or other } \\
\text { associations, and national or } \\
\text { international advocacy } \\
\text { organizations, grievance } \\
\text { mechanisms customer privacy, } \\
\text { diversity, ethics. } \\
\text { Operations with local community } \\
\text { engagement, impact assessments, } \\
\text { and development programs } \\
\text { including negative impacts; }\end{array}$ & & & & & Best-in-Class & Leader & Follower & Starter \\
\hline
\end{tabular}

Source: (GRI 2016; Chen et al. 2015; Dong and Xu 2016) 